\title{
The HIV/AIDS prevention project for vulnerable youth in northern Nigeria: Community advocates training manual
}

Population Council

Adolescent Health and Information Projects

Federation of Muslim Women's Associations in Nigeria

Islamic Education Trust

Follow this and additional works at: https://knowledgecommons.popcouncil.org/departments_sbsr-hiv

Part of the Demography, Population, and Ecology Commons, Family, Life Course, and Society Commons, International Public Health Commons, and the Medicine and Health Commons How does access to this work benefit you? Let us know!

\section{Recommended Citation}

Population Council, Adolescent Health and Information Projects, Federation of Muslim Women's Associations in Nigeria, and Islamic Education Trust. 2007. "The HIV/AIDS prevention project for vulnerable youth in northern Nigeria: Community advocates training manual." Abuja: Population Council. 


\section{(f) Population Council \\ COMMUNITY ADVOCATES TRAINING MANUAL}

"THE HIV/AIDS PREVENTION PROJECT FOR VULNERABLE YOUTH IN NORTHERN NIGERIA"
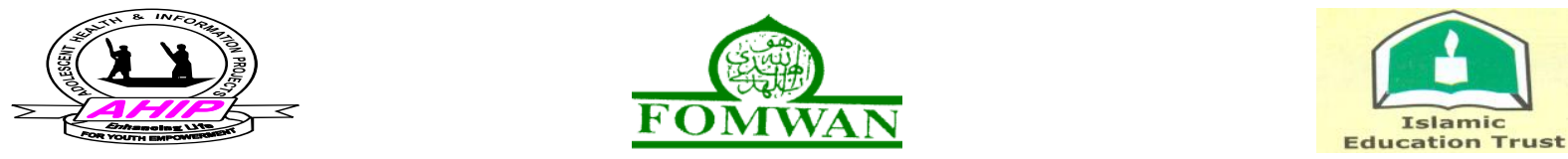


\section{Acknowledgements}

The Community Advocates Training Manual is a joint effort between Population Council/Abuja and its partners - Adolescent Health Information Projects (AHIP), Federation of Muslim Women Associations in Nigeria (FOMWAN) and Islamic Education Trust (IET). The Population Council would like to thank all who have contributed their time, skills and expertise towards the production of the manual.

We recognize the efforts of the Education as a Vaccine Against AIDS (EVA) Consultants, Ms. Fadekemi Akinfaderin and Ms. Martha Nambuyaga whose vast knowledge of HIV/AIDS and adolescent reproductive/sexual health in Nigeria was invaluable in the development of this advocacy training manual.

Invaluable support was also provided by those who reviewed drafts of the manual or provided other technical advice and support including Haj. Mairo Bello (AHIP), Haj. Maryann Othman (FOMWAN) and Alh. Abdurrahim Suliaman(IET).
We also want to recognize the assistance received from the facilitators of our partner organizations during workshops to pre-test the manual in the F.C.T, Niger and Benue states.

Our sincere thanks are extended to Pastors Bisi Akande and Laide Adenuga of the Redeemed Christian Church' HIV/AIDS Program in reviewing the Biblical scriptures used. In addition to the assistance of IET for the inclusion of Qur'an and Hadith verses, we acknowledge the use of the DfID- funded Technical Report and Proceedings of the Nigerian Muslim Leaders' Training on HIV/AIDS and Islam.

And we recognize the collaborative efforts of all Population Council staff involved both locally and in the regional office.

Finally, our gratitude goes to USAID/Nigeria. Without their generous financial support for the project, the development of the Community Advocates Training Manual may not have been possible. 


\section{Table of Contents}

Acknowledgements............................................2

Table of Contents..............................................3

Acronyms.........................................................4

Introduction...............................................6

\section{MODULE ONE:}

The Training Environment.................................9

Session 1:

Session 2:

Session 3:

Session 4:

Session 5:

Group Introductions

Expectations and Fears

.11

Ground Rules .................................12

Project and Workshop Overview........13

Team Building.

\section{MODULE TWO:}

Introduction to Advocacy.............................15

Session 1: $\quad$ Our Advocacy Experience.....................16

Session 2: $\quad$ What is Advocacy? .............................17

Session 3: $\quad$ Advocacy -vs- Other Strategies .......18

Session 4: $\quad$ Benefits of Advocacy .........................19

Session 5: $\quad$ Advocacy Methods.............................20

\section{MODULE THREE:}

\section{HIV/AIDS \& SRH Issues.}

.22

Session 1: Values Clarification...........................23

Session 2: $\quad$ Values and Behavior........................25

Session 3: $\quad$ HIV/AIDS Basic Facts......................27

Session 4: HIV/AIDS Transmission...................28

Session 5: $\quad$ HIV Prevention (ABC).......................30

Session 6: HIV Prevention (PMTCT)..................32

Session 7: $\quad$ HIV Risks and Vulnerability..............34

Session 8: $\quad$ Voluntary Counseling \& Testing.....36

Session 9: $\quad$ ARV and Positive Living....................38

Session 10: Stigma and Discrimination................39

Session 11: Sexually Transmitted Infections......41

Session 12: Child Birth Spacing..........................42

Session 13: Safe Motherhood..............................44

Session 14: Gender Roles...................................45

Session 15: Early Marriage and Its Risks..........47

Session 16: $\quad$ Gender Based Violence....................49

Session 17: Couple Communication.....................51 


\section{Table of Contents II}

\section{MODULE FOUR:} Advocacy Skills. .53

Session 1: Communication (Muddling Messages)....54

Session 2: $\quad$ Communication (Listening Pairs).............55

Session 3: $\quad$ Communication (Body Language)...........56

Session 4: Overview of Communication.....................57

Session 5: $\quad$ Overview of Negotiation...........................58

Session 6: Lobbying/Face to Face Meeting..............60

Session 7: Facilitating Discussions...........................62

Session 8: $\quad$ Making Presentations .............................64

Session 9: Drama Presentations................................66

Session 10: Conducting a Media Interview................68

Session 11: Effective Referrals..................................70

\section{MODULE FIVE:}

Planning and $M$ \& $E$

.71

Session 1: Action Plans......................................72

Session 2: Activity/Event Logistical Planning....73

Session 3: $\quad$ Monitoring and Record Keeping.......74

Session 4: Evaluation. 


\section{Acronyms}

- $\quad$ AIDS

- $\mathrm{ARV}$

- $\quad$ ASRH

- COC

- $\mathrm{ECP}$

- $\mathrm{FGC} / \mathrm{M}$

- $\mathrm{GBV}$

- haART

- HIV

- HTP

- IEC

- ICPD

- IPC

- $\quad M \& E$

- OCP

- OI

- $\mathrm{PC}$

- PID

- PLWHA

- PMTCT

- $\mathrm{RH}$

- $\quad$ RVF

- $\mathrm{SRH}$

- STD

- STI

- USAID

- VCT

- VVF
Acquired Immunodeficiency Syndrome

Anti-Retroviral Drugs

Adolescent Sexual/Reproductive health

Combined Oral Contraceptives

Emergency Contraceptives Pills

Female Genital Cutting/Mutilation

Gender Based Violence

Highly Active Antiretroviral Therapy

Human Immunodeficiency Virus

Harmful Traditional Practices

Information, Education \& Communication

International Conference on Population and Development

Inter-Personal Communication

Monitoring and Evaluation

Oral Contraceptive Pills

Opportunistic Infections

Population Council

Pelvic Inflammatory Disease

People Living with HIV/AIDS

Prevention of Mother-to-Child Transmission

Reproductive Health

Recto-Vaginal Fistula

Sexual and Reproductive Health

Sexually Transmitted Disease

Sexually Transmitted Infection

United States Agency for International Development

Voluntary Counseling Testing

Vesico-Vaginal Fistula 


\section{Introduction}

The Community Advocates training manual is a curriculum developed by Population Council, Nigeria under the HIV Prevention Project for Vulnerable Youth in Northern Nigeria funded by USAID/Nigeria. The curriculum was developed as a tool for training community advocates to conduct advocacy activities on the issues of early marriage, HIV/AIDS and reproductive health. The curriculum is developed on the premise that community representatives can speak out on issues concerning their lives and community, if given the necessary skills.

The curriculum aims to improve knowledge and strengthen the skills of community representatives from the northern region of Nigeria to openly discuss sensitive issues relating to HIV/AIDS, reproductive health and marriage. The curriculum features participatory activities that will help community advocates to:

- Differentiate advocacy activities from other types of HIV/AIDS strategies

- Think creatively about different approaches to advocacy

- Learn and explore critical issues relating to HIV/AIDS and reproductive health

- Develop skills such as communication, presentation, facilitation and conducting media interviews. 


\section{Introduction}

The curriculum is divided into five modules made up of 40-60 minute sessions. The modules are created based on themes as follows:

- Training Environment: This module sets the atmosphere for the training. The purpose of this module is to enable participants to get acquainted, feel relaxed and comfortable as well as setting rules to guide the training

- Background on Advocacy: The module provides a brief introduction to advocacy. It enables the participants to have a shared understanding of the definition of advocacy, benefits of advocacy and explore how advocacy is being used in their everyday life routine.

- $\quad H I V / A I D S$ and SRH issues: This module is the knowledge-based module of the manual. Its purpose is to provide participants with as much information as possible on key HIV/AIDS and reproductive health issues relating to marriage and adolescent.

- Advocacy skills: This module is the skills-based component of the manual. Participants will learn the basic skills needed to carry out advocacy and examine some sample advocacy activities.

- Planning and M\&E: As the final module, this component enables the participants to develop action points and plans to put knowledge into practices back into their communities.

In addition to the modules, the curriculum also includes facilitators reference notes and sample activities for icebreakers/energizers 


\section{Introduction}

The curriculum should be implemented by a trainer with good facilitation skills and basic knowledge about the subject matter. Given the target audience, it might be applicable to facilitate the sessions in the local languages. The curriculum activities has been designed to take into consideration the literacy levels of the target audience. The curriculum is developed to engage the participants through the "learning by doing" approach that will encourage reflection based on personal/community circumstances and sharing of experiences.

The curriculum was designed to be adapted or implemented as it is written, based on the needs of the facilitators and trainees. Prior to the implementation of any session, it is important for the facilitator(s) to review the reference notes and each session outline in detail. Some sessions may require the selection of other facilitators such as in the case of "ARV and Positive Living" session to enrich the content and delivery of the topic.

It is hoped that this manual will be a valuable resource to the project communities as well as other partners/organizations interested in mobilizing and engaging community representatives in advocacy efforts on HIV/AIDS and reproductive health issues. 


\section{Module Overview}

\section{Module 1: The Training Environment}

This module sets the atmosphere for the training. The purpose of this module is to enable participants to get acquainted, feel relaxed and comfortable as well as setting rules to guide the training. Details of the project and purpose of the workshop will also be discussed.

Session 1 Group Introductions

Session 2 Expectations and Fears

Session 3 Ground Rules

Session 4 Project and Workshop Overview

Session 5 Team Building and Work
30 mins

30 mins

30 mins

50 mins

40 mins

Total Module Time: $\quad 3$ hours (180 minutes) 


\section{Session 1: Group Introduction}

Title: $\quad$ The Name Game
Time: $\quad 30$ minutes
Materials:
- Naries based on group size)
Objectives:
- Enable the participants to get to know
each other in a friendly environment
Notes:
- Stress that the animal choice is just a
game and not a true reflection of their
character or person
If a participant can't remember an
animal, don't let them get embarrassed,
encourage the group to help
Assist participants who can't write to
include their name in their name tags.

\section{Process}

- Welcome the participants to the workshop. Before going into details about the program, it is important to get to know each other. To help us know each other, we are going to play a game called the "name game"

- $\quad$ Ask participants to form a circle either standing or in their seats.

- Using yourself as the $1^{\text {st }}$ example, tell the participants your name and an animal you like or that best represents your personality.

- $\quad$ For example, my name is "Aisha and I like ants"; "Áhmed and I like antelopes".

- $\quad G o$ around the circle asking the participants to do the same until all participants have taken turns.

- $\quad$ Ask the participants to write their animals on their name tag and explain that this will be the name that they will be called through out the duration of the workshop. 


\section{Session 2: Expectations and Fears}

Title: $\quad$ Our Expectation and Fears

Time: $\quad 30$ minutes

Materials:

- $\quad$ Flip charts

- Markers

\section{Objectives:}

- $\quad$ Participants will voice their feelings about the workshop

- $\quad$ Gauge the participant's understanding of workshop activities and their interest

\section{Notes:}

- $\quad$ Provide additional examples for participants, if there seems to be any confusion on the exercise.

- You can ask for a volunteer to provide explanations to other participants

\section{Process}

- $\quad$ Tell the participants the next activity to be conducted is to help the facilitator understand what the participants are thinking about the workshop.

- Going around in the circle, ask each participant to mention a hope and a fear they have on the workshop using the format " I hope that...." and "I fear that....".

- Use yourself as an example to illustrate for the participants.

- $\quad$ Record their responses on separate paper

- $\quad$ Once everyone has responded, examine the hopes listed and clarify any hopes that are beyond the scope of the workshop

- $\quad$ For the fears, try to reassure participants and provide clarification where needed.

- $\quad$ Ask everyone to remember their hopes and fears because at the end of the workshop, they will review it together to see if the hopes are met and the fears were addressed. 


\section{Session 3: Ground Rules}

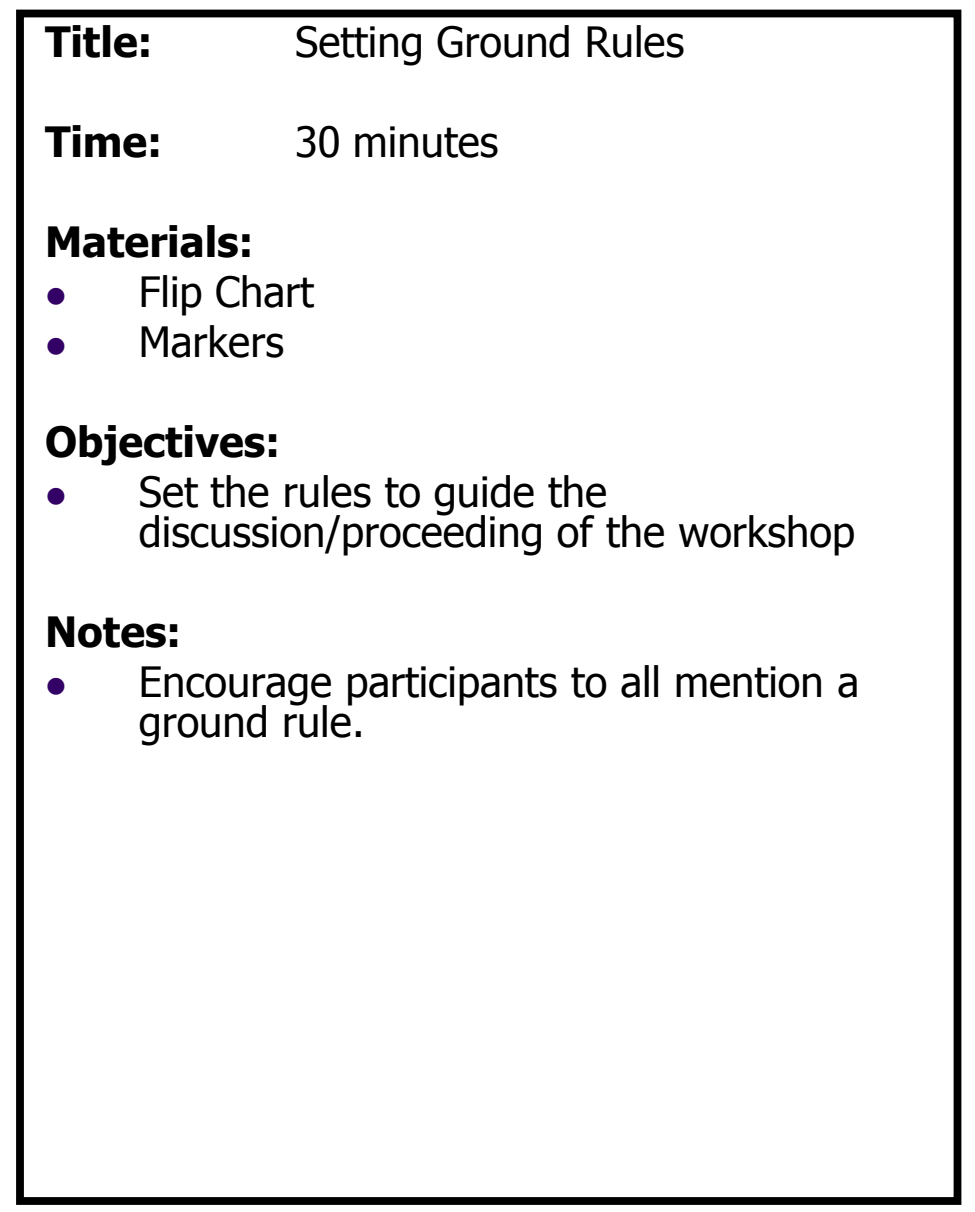

\section{Process}

- Introduce the concepts of ground rules to the participants by reading the statement:

This time we are going to spend together we have to use it usefully. To guide us in our discussions, we need to have rules/laws. As in every society, there are rules and regulations that the people have to follow. For this workshop and our other meetings we need to have rules/laws that will make our discussions fruitful.

- $\quad$ Ask each participant to mention at least one rule/law that the group should follow in the workshop and other project activities.

- $\quad$ Flip chart/record each response and make any addition that might be omitted

- $\quad$ Ask the group to nominate a person to serve as a police to enforce the rules.

- $\quad$ Tape the ground rules on the wall where it can be seen by everyone 


\section{Session 4: Project and Workshop Overview}

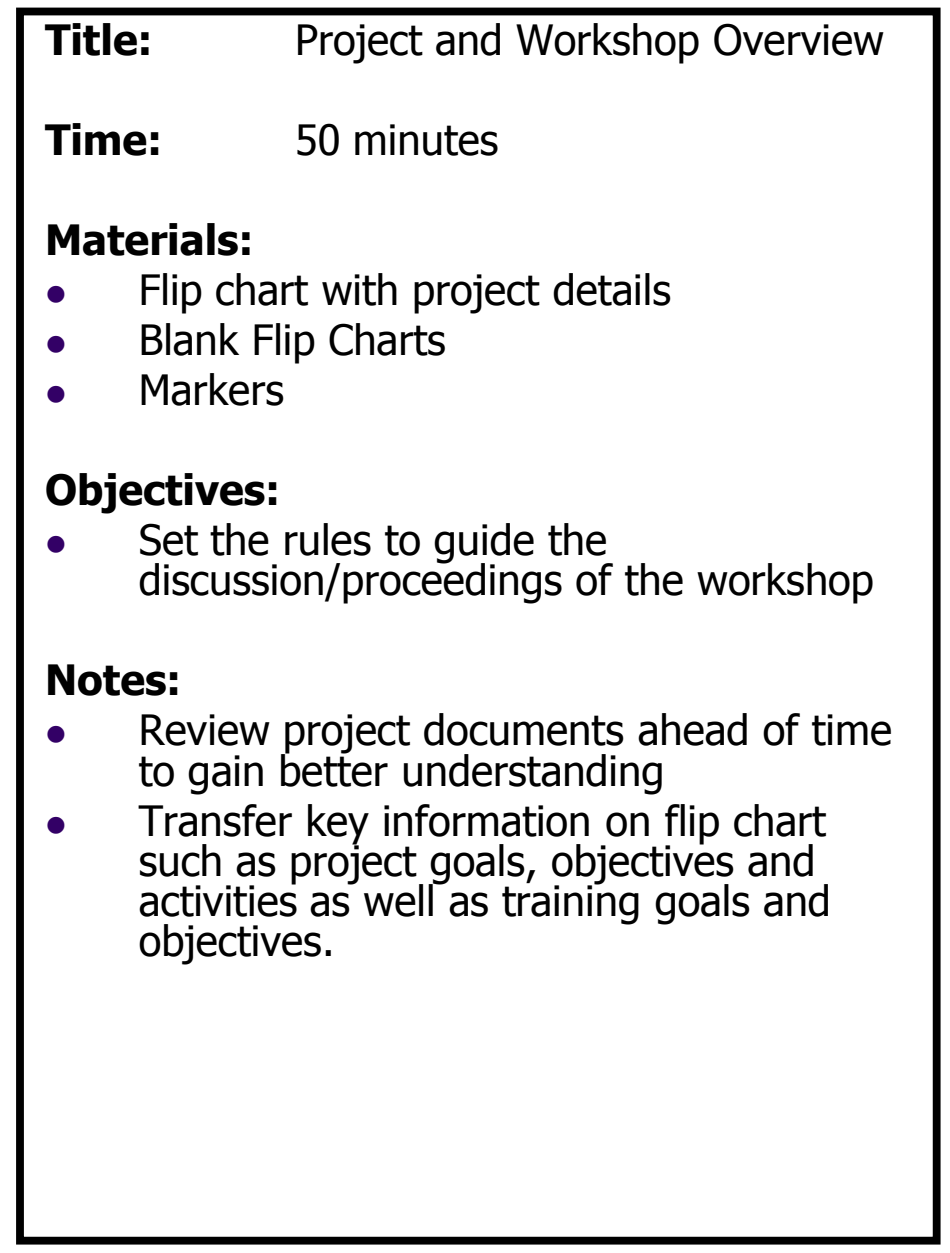

\section{Process}

- Give a brief introduction about the organization and it's activities

- $\quad$ Give detailed information about the project focusing on the goal; objectives and the activities

- $\quad$ Paste flip chart with workshop goals and objectives

- $\quad$ Review with the participants and highlight the expectation/requirements of participants after completion of the training

- Make linkages between the project activities and training goals/objectives

- Allot 10 minutes for questions and answers from the participants. 


\section{Title: \\ The Straight Line}

Time:

40 minutes

\section{Materials:}

- Scarf or blindfold

\section{Objectives:}

- $\quad$ Enables participants to experience the value of team support and cooperation

\section{Notes:}

- $\quad$ Remember to select a path for walking away from dangerous materials

- $\quad$ The exercise can be repeated with $2 / 3$ volunteers for more people to experience the activity.

\section{Process}

- Define/set a walk path in the training venue.

- $\quad$ Invite a volunteer to come forward and walk slowly in a straight line in this path. Immediately this is done, place the blind fold/scarf over their eyes

- $\quad$ Ask the volunteer to walk in a straight line again from the beginning to the end point. Instruct the rest of the group members to be completely silent, giving no guidance. They should also not touch the person

- When the person reaches the other side, remove the blind fold and compare how close they were to the intended location. Ask the volunteer to mention how s/he felt about the exercise

- Repeat the exercise again, but this time with the group members providing support with only verbal directions

- $\quad$ Repeat the exercise again with the group members giving physical support such as holding hands and talking

- On completion, remove the blind fold and discuss with the group what the purpose of the exercise was and how it relates to the workshop.

- $\quad$ Conclude by mentioning the importance of team work in the workshop 


\section{Module Overview}

\section{Module 2: Background to Advocacy}

The purpose of this module is to enable the participants to have a shared understanding of what advocacy is. It will also help them to identify the benefits of advocacy and explore how advocacy is being used in their everyday life/routine.

Session 1 Our Advocacy Experience

40 mins

Session 2 What is advocacy?

30 mins

Session 3 Differentiating between Advocacy and Other Strategies

30 mins

Session 4 Benefits of Advocacy

40 mins

Session 5 Common Methods for doing Advocacy Work

40 mins

Total Module Time: $\quad 3$ hours (180 minutes) 


\section{Session 1: Our Advocacy Experience}

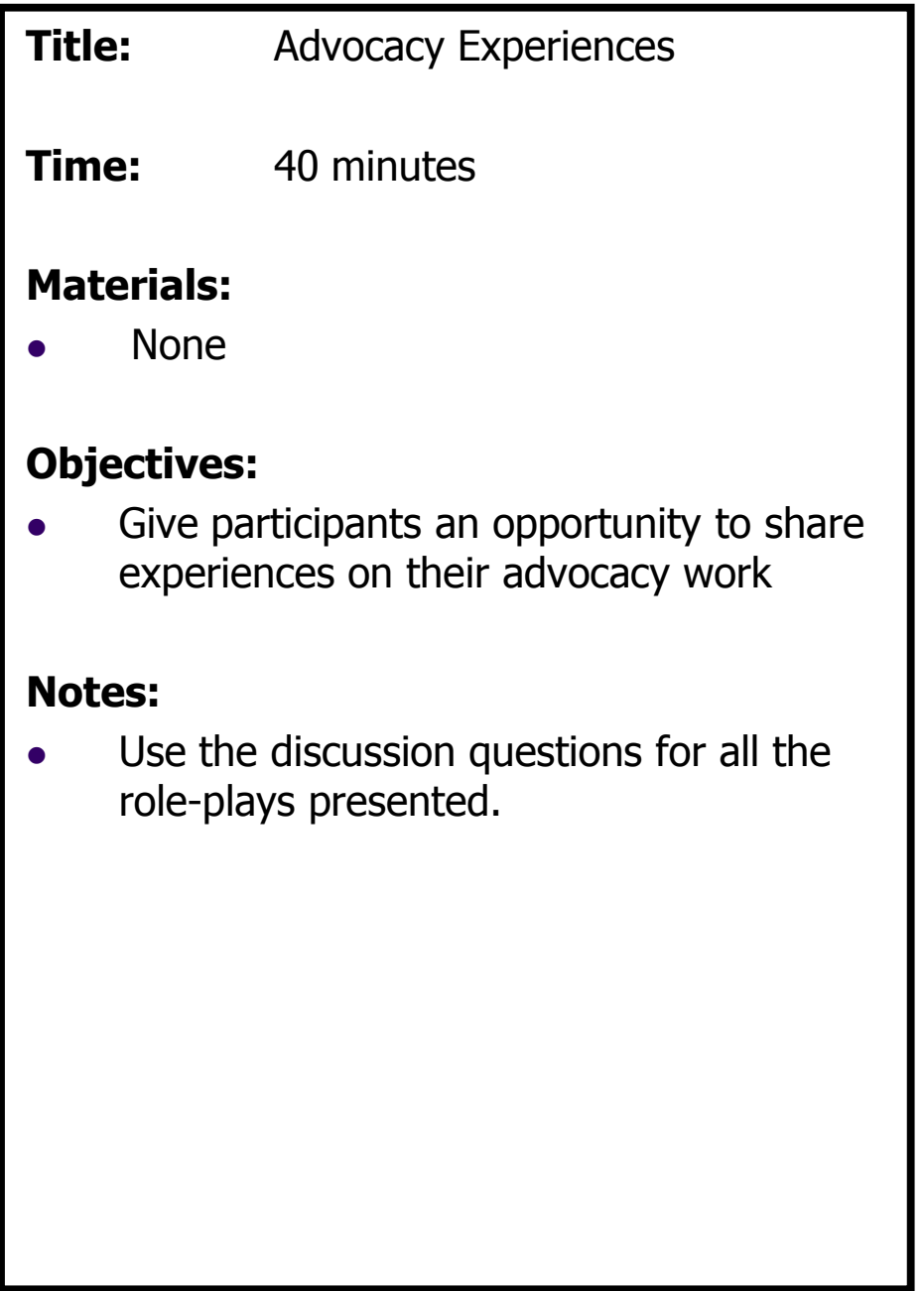

\section{Process}

- $\quad$ Begin the session with the following introductory statement. "Advocacy is not a new concept to us, many of us have been engaged in advocacy activities in our working places or personal lives. Before we can formally begin this session, we need to make sure that we have the same understanding of what advocacy is".

- Break participants into three groups and ask them to develop a 2 minute role-play of an advocacy activity they have conducted in their professional or personal lives. Allocate 15 minutes for brainstorming and practice within their groups.

- $\quad$ Each group should make their presentation in plenary. Facilitate a group discussion using the following questions as a guide.

1. What issues were addressed in the roleplay?

2. What advocacy approach or method was used in the role-play?

3. Who benefited from the advocacy activity?

4. Why was the use of advocacy important? 


\section{Session 2: What is Advocacy?}

\begin{tabular}{|c|c|}
\hline $\begin{array}{l}\text { Title: What is Advocacy? } \\
\text { Time: } \quad 30 \text { minutes } \\
\text { Materials: } \\
\text { - } \quad \text { Flip Chart paper } \\
\text { Markers } \\
\text { Objectives: } \\
\text { - To develop a shared definition of advocacy } \\
\text { Notes: } \\
\text { - Make sure that the final definition } \\
\text { suggested encompasses some of the key } \\
\text { elements of advocacy. } \\
\text { Possible definition can be "Advocacy is a } \\
\text { process that brings about change in laws, } \\
\text { policies and practices by persuading } \\
\text { individuals, groups or institutions" }\end{array}$ & $\begin{array}{l}\text { Process } \\
\text { Thank participants for completing the last } \\
\text { exercise. Explain that it is obvious from } \\
\text { the presentations that most people in the } \\
\text { group are familiar with advocacy. The } \\
\text { next activity is for the entire house to try } \\
\text { to develop one good definition of what } \\
\text { advocacy is based on these experiences } \\
\text { Going around the room, ask each } \\
\text { participant to provide a definition of what } \\
\text { advocacy means to them. Flip } \\
\text { chart/record responses } \\
\text { After each participant has provided a } \\
\text { response, ask for volunteers to attempt } \\
\text { to harmonize the definitions and create a } \\
\text { new definition that captures most of the } \\
\text { key elements in the brainstormed list. } \\
\text { Note down new harmonized definitions } \\
\text { and ask the participants to vote on the } \\
\text { most appropriate definition that captures } \\
\text { their experience. } \\
\text { Upon selection of a group definition, } \\
\text { inform participants that there is no } \\
\text { standard definition of advocacy, so the } \\
\text { provided definition will be the acceptable } \\
\text { standard for the workshop }\end{array}$ \\
\hline
\end{tabular}




Title: $\quad$ Advocacy -vs- Other Strategies
Time: $\quad 30$ minutes
Materials:
- Flip chart with "Strategies Comparison
$\quad$ Table"
Objectives:
Differentiate between advocacy and other
strategies such as IEC and community
mobilization
Notes:
Prepare flip chart with "strategies
comparison table" ahead of time

\section{Process}

- $\quad$ Read: "Often there is a lot of confusion between advocacy and other terms like information, education and communication (IEC) and community mobilization. This is because IEC and community mobilization can also involve influencing, persuading and mobilizing people into action. These are all advocacy key words and we are going to explore the differences between these terms in the session.

- $\quad$ Paste flip chart with table on the wall and go through each section.

- $\quad$ Ask for volunteers to provide specific examples for each of the strategies presented in the table.

- If there are no volunteers, provide specific examples that are relevant to their communities/settings

- $\quad$ Provide 10 minutes for questions and further clarifications

- $\quad$ Round up the session by asking for volunteers to mention the differences between advocacy and some of the other strategies. 


\section{Session 4: Benefits of Advocacy}

\section{Title: Benefits of Advocacy}

Time: $\quad 40$ minutes

\section{Materials:}

- $\quad$ Flip chart

\section{Objectives:}

- Identify the benefits to conducting advocacy

\section{Notes:}

- Encourage each participant to contribute regardless of the accuracy of their response

- Review notes on the benefits of advocacy

\section{Process}

- $\quad$ Read out the following statement: "We have defined advocacy and have compared it to other types of strategies available. The next activity, we are going to try to identify the benefits of advocacy"

- $\quad$ Place a flip chart on the wall and going around in a circle, ask each participant to say 1 benefit of advocacy. Flip chart/record the response.

- $\quad$ Continue going around, until the group has exhausted their responses. Examine the responses and add any other benefit that might have been omitted.

- $\quad$ Divide the participants into 2 groups and ask them to develop a 3 minute television or radio advertisement that captures the benefits of advocacy brainstormed on the flip chart. Assign 10 minutes for the task.

- $\quad$ After the time has elapsed, ask each group to make their presentations.

- $\quad$ Conclude by asking the groups to state 3 things they like about the presentations made and what they learned about advocacy from the presentation. 


\section{Session 5: Advocacy Methods}

\begin{tabular}{|c|c|}
\hline $\begin{array}{l}\text { Title: Common Methods in Advocacy } \\
\text { Time: } 40 \text { minutes } \\
\text { Materials: } \\
\text { - } \quad \text { Flip charts } \\
\text { - Markers } \\
\text { Objectives: } \\
\text { List and describe the different } \\
\text { methods that can be used as part of } \\
\text { advocacy } \\
\text { Notes: } \\
\text { Make sure you observe group work } \\
\text { as it's being conducted } \\
\text { Review notes on advocacy methods }\end{array}$ & $\begin{array}{l}\text { Process } \\
\text { Tell participants that they have reached } \\
\text { the final part of this module. But before } \\
\text { concluding it is important to explore the } \\
\text { different methods of advocacy. Advocacy } \\
\text { can take many forms, the length of time is } \\
\text { also different and we can conduct } \\
\text { advocacy on our own or with a group. } \\
\text { Break participants into } 2 \text { groups. } \\
\text { Ask participants to make a list of ways } \\
\text { they have persuaded community leaders } \\
\text { or political leaders to change something } \\
\text { they were not happy with. } \\
\text { After the groups have made their lists, ask } \\
\text { these same groups to make another list. } \\
\text { This second list should include methods } \\
\text { they have used to persuade members of } \\
\text { their families, friends or neighbors of their } \\
\text { point of view on an issue they have felt } \\
\text { strongly about. } \\
\text { Allot } 15 \text { minutes for the task } \\
\text { Bring everyone back into one group. Ask } \\
\text { each group to briefly present their lists. }\end{array}$ \\
\hline
\end{tabular}




\section{Process 2}

- Facilitate a discussion to bring out the range of different possible methods used to do advocacy work, using the following questions

1. Do the two lists overlap? If so, what does this overlap tell us?

2. How do we decide which method to use?

3. How can the people directly affected by the advocacy issue be involved in advocacy work? Or how can they give their permission for the advocacy work?

- Note some of the methods that are emerging from the discussion on flip chart.

- Add any additional methods that might be omitted to the list

- Summarize the session by asking each participant to read what methods are listed on the flip chart.

- Make additional clarifications if there are any questions from the group about a specific methods

- Round up by thanking participants for active contribution 


\section{Module Overview}

\section{Module 3: HIV and SRH Issues}

This module is the knowledge based module of the manual. Its purpose is to provide participants with as much information as possible on key HIV/AIDS and reproductive health issues relating to marriage and adolescents. The topics are fact based and incorporate experiential learning techniques .

$\begin{array}{llr}\text { Session 1 } & \text { Values Clarification } & 40 \text { mins } \\ \text { Session 2 } & \text { Value and Behaviors } & 40 \text { mins } \\ \text { Session 3 } & \text { HIV/AIDS Basic Facts } & 40 \text { mins } \\ \text { Session 4 } & \text { HIV Transmission } & 40 \text { mins } \\ \text { Session 5 } & \text { HIV Prevention (ABC) } & 120 \text { mins } \\ \text { Session 6 } & \text { PMTCT } & 60 \text { mins } \\ \text { Session 7 } & \text { HIV Risk \& Vulnerability } & 60 \text { mins } \\ \text { Session 8 } & \text { VCT } & 60 \text { mins } \\ \text { Session 9 } & \text { ARV \& Positive Living } & 90 \text { mins }\end{array}$

Session 10 Stigma \& Discrimination

60 mins

Session 11 Sexually Transmitted Infections 60 mins

Session 12 Birth Spacing

90 mins

Session 13 Safe Motherhood

60 mins

Session 14 Gender Roles

60 mins

Session 15 Early Marriage and Its Risks

90 mins

Session 16 Gender Based Violence

90 mins

Session 17 Couple communication

60 mins

Total Module Time: 18.6 hours (1120 minutes) 


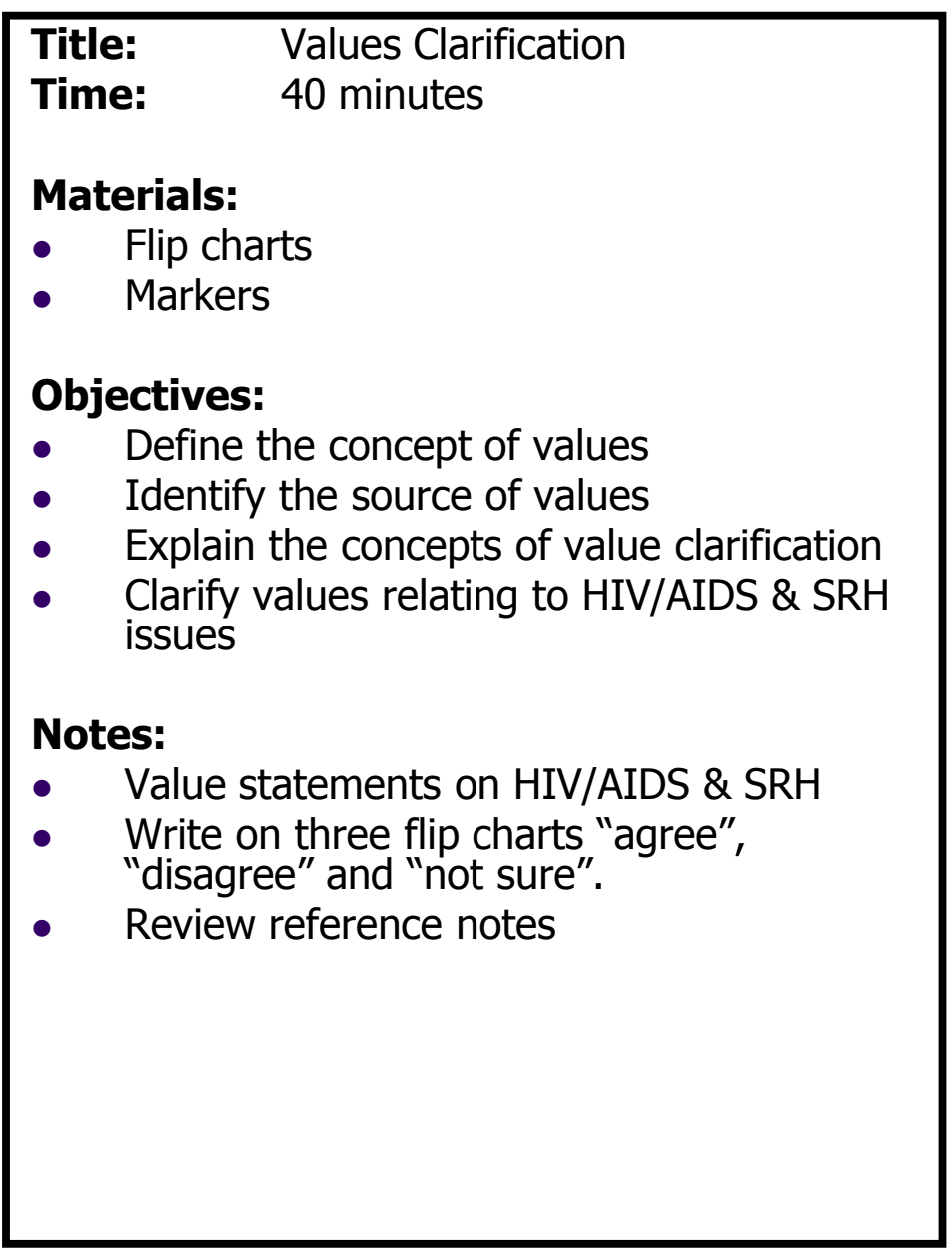

\section{Process}

- Read the statement to introduce the topic: "Before we can begin the next module, we need to explore our views of HIV/AIDS and reproductive health issues."

- $\quad$ Ask participants to define the word "values", flip chart/record responses.

- Clarify definition, stressing that our values are things we hold in high esteem that are important to an individual. Values influence the way we see things and behave.

- $\quad$ Ask participants to brainstorm sources of our values. Flip chart/record these responses.

- Include any source that is not mentioned.

- $\quad$ Present the definition of values clarification and stress that it is important to check our values because it affects the way an individual behaves. As community advocates it would also affect the type of information we provide to our community and members.

- Place "agree", "disagree" and "not sure" flip charts at different locations in the training room. 


\section{Session 1: Values Clarification}

\section{Process 2}

- Tell participants that they are going to clarify their values in a game.

- Inform them that for each statement you will read, they should move under the signs (agree, unsure and disagree) based on their views/feelings on the statement.

- Read each statement out loud. Based on their response, ask for volunteers to define their choice.

- Note the number and perception of participants for each statement.

- $\quad$ After each statement, make additional clarification as needed.

- $\quad$ Complete all the statements and allocate a few minutes for questions.

\section{Statements}

1. HIV is a punishment for sexual sins

2. Birth spacing should not be encouraged because it's a foreign concept

3. There is no use to HIV testing because it is just a death sentence

4. Antenatal care is a waste of money

5. PLWHA should not be allowed to have children

6. A wife deserves to be beaten if she is disrespectful to her husband

7. A woman who is HIV positive has been unfaithful.

8. Young people should marry at an early age to prevent the spread of HIV in the community 


\section{Session 2: Values and Behaviors}

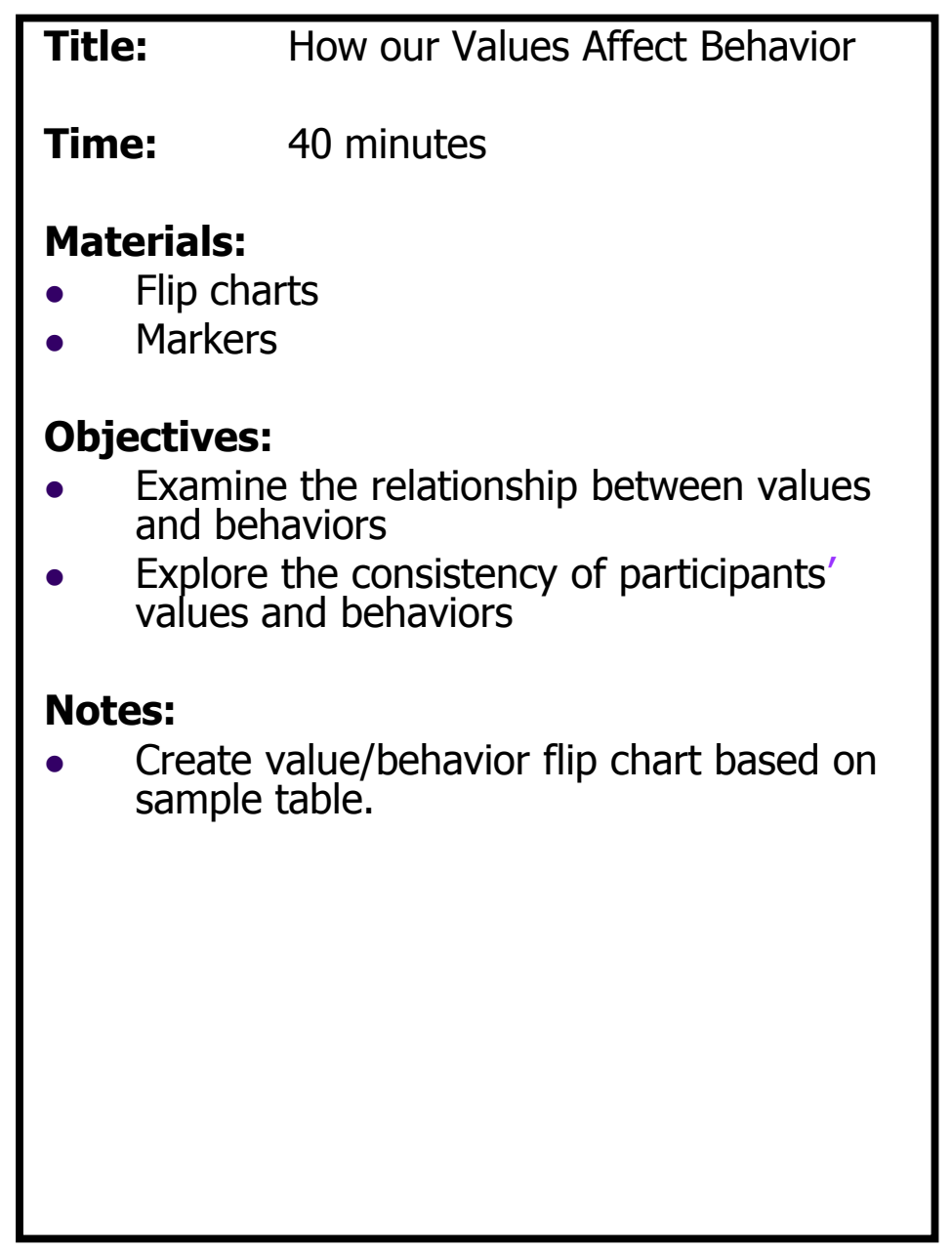

Process

- $\quad$ Read the statement to the participants: In the last activity we examined what are values. In this activity, we are going to look at how our values affect our behaviors.

- Place the values/behavior flip chart on the wall.

- $\quad$ Ask each participant to respond to the following questions by raising their hands and note the number of respondents on the flip chart for each question.

- $\quad$ First read the value statement and then ask the questions.

- At the end of the task, review the response out loud.

- $\quad$ Ask the participants to reflect on their answers and brainstorm why people don't act according to their values.

- Conclude the session by discussing the following questions

- How does it feel when your values are not inline with your behaviors?

- If the values and behaviors are different, which one should you reevaluate?

- Why is this important for our work as community advocates? 


\section{Session 2: Values and Behaviors}

\section{Value Statements and Questions}

- Men and women should have equal opportunities

- I would encourage my sister/daughter to become a mechanic

- I would allow my son to take a sewing class

- I feel it is okay to have a female supervisor/boss

- Health is very important

- I exercise regularly

- I eat a balance meal

- I eat three meals a day

- I smoke

- I drink alcohol

\begin{tabular}{|l|l|l|}
\hline $\begin{array}{l}\text { Flip Chart } \\
\text { Sample } \\
\text { Statement }\end{array}$ & Agree/Do & $\begin{array}{l}\text { Disagree/ } \\
\text { Don't Do }\end{array}$ \\
\hline $\begin{array}{l}\text { Men and Women } \\
\text { should have equal } \\
\text { opportunity }\end{array}$ & & \\
\hline $\begin{array}{l}\text { I would encourage } \\
\text { my sister/daughter } \\
\text { to become a } \\
\text { mechanic }\end{array}$ & & \\
\hline $\begin{array}{l}\text { Health is very } \\
\text { important }\end{array}$ & & \\
\hline $\begin{array}{l}\text { I exercise } \\
\text { regularly }\end{array}$ & & \\
\hline
\end{tabular}




\section{Session 3: HIV/AIDS Basic Facts}

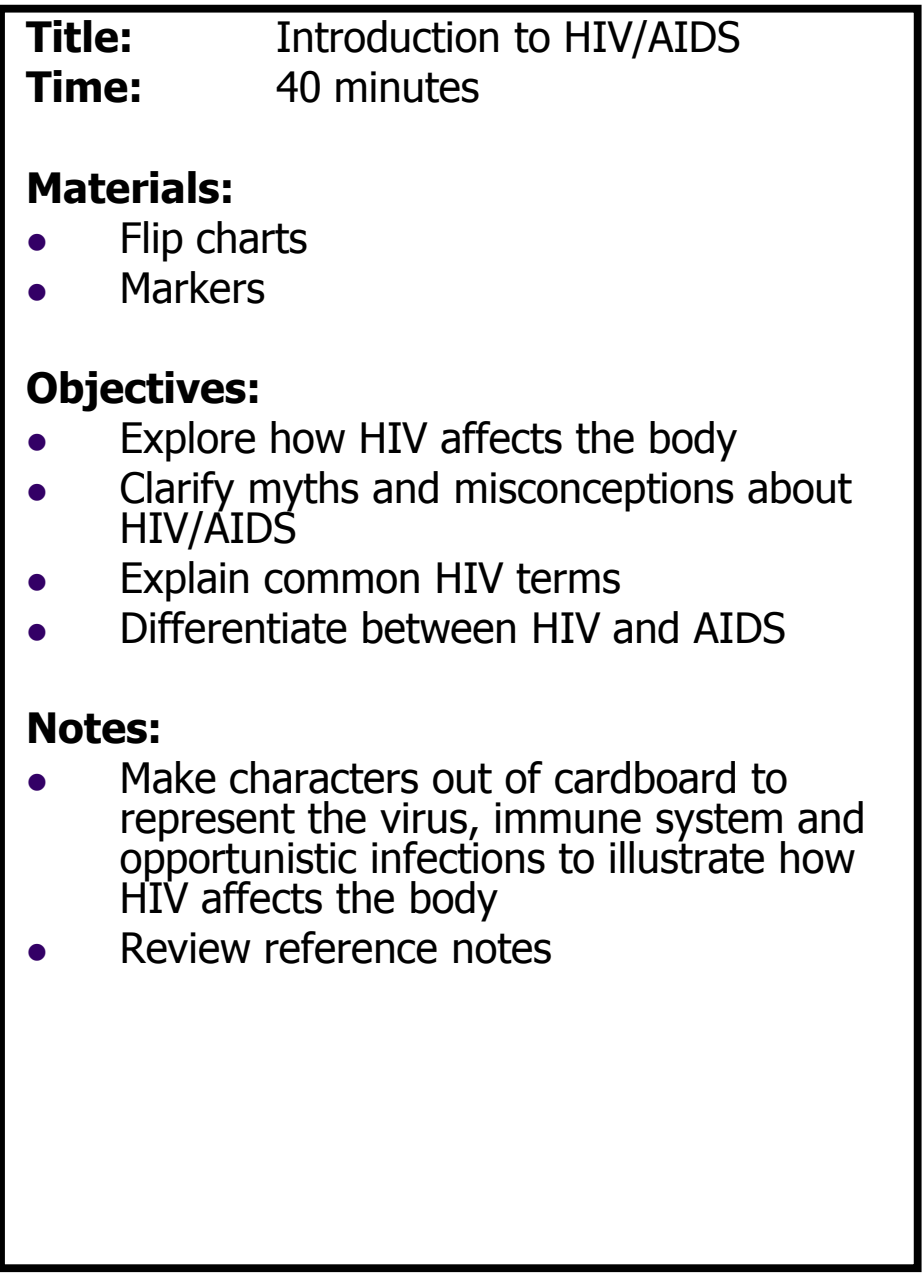

\section{Process}

- Introduce the topic by asking how many participants have heard of HIV/AIDS.

- $\quad$ Going around the room, ask each person to say one thing they have heard, this should also include questions they might have about the topic. Flip chart/record responses

- $\quad$ Using these responses, clarify questions and misconceptions.

- $\quad$ Place flipcharts with the words HIV and AIDS on the wall.

- Ask for volunteers to provide the full meaning of HIV and AIDS.

- $\quad$ Review the differences between HIV and AIDS, also highlight the symptoms of a person living with AIDS.

- Using play models, illustrate how HIV/AIDS affects the body to the participants.

- $\quad$ Remember to mention key words such as immune system; white blood cells; virus etc.

- Conclude by allocating 10 minutes for questions from participants. 
Session 4: HIV Transmission The Islamic approach to HIV/AIDS includes educating communities about

it - It is only those who have knowledge among his laves that fear Allah. Verily Allah is All Mighty, Oft-Forgiving...seek knowledge. (Q35:28); (1 John 4:16) "God is love, and he who abides in love abides in God and God in him." (Psalms 82:5) "They know not, neither will they understand; they walk on in darkness..."

\begin{tabular}{|c|c|}
\hline $\begin{array}{l}\text { Title: HIV Transmission } \\
\text { Time: } 90 \text { minutes } \\
\text { Materials: } \\
\text { - } \quad \text { Flip charts } \\
\text { Markers } \\
\text { Objectives: } \\
\text { - } \quad \text { List the fluids and opening in the body } \\
\text { - } \quad \text { Explore the route or modes of HIV } \\
\text { transmission } \\
\text { - } \quad \text { Clarify misconceptions about HIV } \\
\text { transmission and refer where available } \\
\text { relevant quotes from Qur'an \& Bible } \\
\text { Notes: } \\
\text { - } \quad \text { Prepare door and fluid flip charts } \\
\text { - Prepare hierarchy of risk table } \\
\text { - } \quad \text { Review reference notes }\end{array}$ & $\begin{array}{l}\text { Process } \\
\text { - Introduce the topic by telling participants } \\
\text { that before we can learn how to prevent } \\
\text { HIV, it is important to learn how it is } \\
\text { transmitted. } \\
\text { Break the participants into small working } \\
\text { groups and assign the task of drawing the } \\
\text { ways in which HIV can be transmitted and } \\
\text { the ways it can not be transmitted. } \\
\text { The drawings should be done on two } \\
\text { separate flip chart papers } \\
\text { - Ask the groups to make their presentation } \\
\text { and to include explanations for their } \\
\text { responses. } \\
\text { Include other modes of transmission that } \\
\text { might not be omitted in the group } \\
\text { presentations } \\
\text { Introduce the concept of "door" and "fluids" } \\
\text { by telling participants that in order for HIV } \\
\text { transmission to take place, there must be a } \\
\text { body fluid and a door. } \\
\text { Place a flip chart with a drawing of a door } \\
\text { on it and another with blood drops on it. } \\
\text { Ask participants to brainstorm all the body } \\
\text { fluids and doors/openings in the body. }\end{array}$ \\
\hline
\end{tabular}




\section{Session 4: HIV Transmission}

\section{Process 2}

- Ensure that all the body fluids are mentioned including tear, urine, saliva (see reference notes)

- For each body fluid, mention the concentration of HIV virus in it.

- Make sure that sores/wounds are also mentioned as doors in the body

- Explain that for the transmission to occur, there must be a fluid with high concentration of the virus or large quantity of that fluid in addition to a door in the body.

- Clarify general misconceptions that might have come up during the brainstorming activity in session \#1.

- $\quad$ Example of these misconceptions could be HIV transmission through kissing, eating with PLWHA etc.

- Present a flip chart with the hierarchy of risk table to provide additional clarification.

- Conclude the session allotting 10 minutes for additional questions. 
Session 5: HIV/AIDS Prevention Muslim leaders have said that having Ulamas and Imams promote Islamic teaching and practices to prevent and control HIV/AIDS is very important and include the 5 pillars to help: Iman/Faith; As-Salat/Prayer (Q29:45); Fasting for Ramadan; Zakat offering of alms helps reduce poverty; and Hajj pilgrimage.(Q23:1-7); (Hosea 4:6a) "My people are destroyed for lack of knowledge..." (Proverbs 11:9b \& 11:14b) "...through knowledge shall the just be delivered" and "...in a multitude of counselors there is safety"

Title: Abstinence, Be Faithful, Condom Use

Time: $\quad 120$ minutes

\section{Materials:}

- $\quad$ Flip charts

- Markers

- $\quad$ Sweets

\section{Objectives:}

- $\quad$ Examine the $A B C$ of prevention

- Understand how easily HIV can be transmitted

- Explore the challenges with the $A B C$ strategies from a cultural and gender perspective

\section{Notes:}

- Buy two different colors of sweets. One should have multi-colored wrapper and the other should be plain

- $\quad$ Prepare 1 paper with letter $A ; 2$ papers with letter $B$ each and 2 papers with letter $C$ each. Review reference notes about $A B C$.

- $\quad$ Conduct a condom demonstration, if participants are not opposed to it.

\section{Process}

- Inform the participants that in order to understand the various ways, HIV can be prevented, they are going to play a game.

- $\quad$ Pick 4 participants and give them 5 multicolored sweets of the same color and give the rest of the participants sweets of another color

- Identify 1 participant, give him/her a paper with the letter $A$ and ask him/her not to exchange sweets with the other participants.

- $\quad$ Give 4 other participants paper with the letters B \& $C$ on it.

- $\quad$ Distribute blank papers to all other participants.

- $\quad$ Ask each of the participants to talk to 4 participants and exchange sweets with them. Once they exchange the sweets, they should write their names on their paper.

- $\quad$ After a few minutes ask the participants to sit down and make sure everyone has 5 sweets.

- Ask for the participants you originally gave the first set of 5 multi-colored sweets to stand up.

- $\quad$ Remind the participants that this is a game and not real life.

- Tell the group that these participants had HIV because the multi-colored sweets represented HIV. 
Session 5: HIV/AIDS Prevention (Q17:32)" And came not near to unlawful sex. Verily, it is a great sin, and an evil way that leads one to hell unless Allah forgives him"... and (Q23:1-7). Many verses from the Holy Qu'ran and Hadith support abstinence from illegal sex to avoid HIV/AIDS: (Q30:21)"And amount His signs is this, that He created for you wives from among yourse/ves, that you may find repose in them...(Q4:34) "Men are the protectors and maintainers of women ...the righteous women are devoutly obedient to Allah and their husbands..." (Psalms 112:5b)"... he will guide his affairs with discretion"

\section{Process 2}

- $\quad$ Ask for all the participants that have sweets that are multi-colored to stand up.

- $\quad$ They should read the list of people on their paper. Then the participants standing should also read the names of people on their paper, until everyone standing has read their names.

- Inform them that at the beginning, only 4 people had the sweets, but now they have passed the HIV sweets to the other people standing.

- Ask for the participant with an A on their card, explain that this person didn't contract HIV because the A stands for Abstinence.

- $\quad$ Ask for the participants with B and $C$ on their cards, explain that the participant didn't contract HIV because the " $\mathrm{B}$ " were faithful to their partners and " $\mathrm{C}$ " used a condom. So even though they exchanged sweets with other people they didn't actually contract the infection.

- $\quad$ Use the discussion points to process after this activity.

- Using the reference notes, go through the $A B C$ of prevention.

\section{Process 3}

- $\quad$ Break the participants into 3 small groups and assign Abstinence for group 1; Be Faithful for group 2 and Condom use to the group 3.

- $\quad$ Ask the groups to discuss possible challenges/limitations of the methods with respect to each their culture/religion.

- $\quad$ A volunteer from each group should make a presentation of points discussed.

- Summarize the discussion by highlighting the inadequacies of each method, especially in relation to marital setting as well as power relationship between men and women.

\section{Discussion Questions}

1. $\quad$ Ask how the people with the HIV sweets feel?

2. Did the people with HIV represented sweets look different from other people, what does this say about HIV infection?

3. Ask the participants who had the ' $A$ ' paper, how they felt about not exchanging sweets with people

4. Ask why is it difficult to not participate in the game when others were playing. 


\section{Session 6: PMTCT}

\begin{tabular}{|l}
\hline Title: $\quad \begin{array}{l}\text { Prevention of Mother to Child } \\
\text { Transmission (PMTCT) }\end{array}$ \\
Time: $\quad 60$ minutes \\
Materials: \\
- $\quad$ Flip charts \\
$\quad$ Markers \\
Objectives: \\
- $\quad$ Review how HIV can be transmitted from \\
mother to child \\
- Identify the importance of VCT in PMTCT \\
List the various elements of PMTCT \\
Explore the options available to an HIV \\
positive mother relating to child bearing \\
Notes: \\
Review reference notes to aid the \\
development of presentation outline
\end{tabular}

\section{Process}

- Inform the participants that other than the $A B C$ of prevention, another method of reducing the spread of the virus is preventing the spread from a mother to child.

- $\quad$ Give a short presentation on mother to child transmission of HIV, highlight how transmission occurs during pregnancy, child delivery and after birth. Also stress the importance of VCT in PMTCT.

- $\quad$ Make a presentation on the various components of PMTCT.

- $\quad$ Allot 10 minutes for clarifications and questions

- $\quad$ Facilitate a discussion using the questions below.

1. Should all pregnant women be tested for HIV?

2. If a woman is HIV negative but her partner is HIV positive, should she be discouraged from getting pregnant?

3. If a woman and her partner are both HIV positive should they be discouraged from starting a family? 


\section{Session 6: PMTCT}

\section{Process}

- $\quad$ Summarize the session by reading the following statement:

It is beneficial for a pregnant woman to get tested because If she chooses to keep her baby, she can obtain information about the

(1) good antenatal care,

(2) how to reduce the risk of transmitting HIV to her baby,

(3) proper care for her baby after birth, including safe alternatives to breast feeding

(4) Birth spacing options after pregnancy and (5) how to keep herself from being re-exposed. 


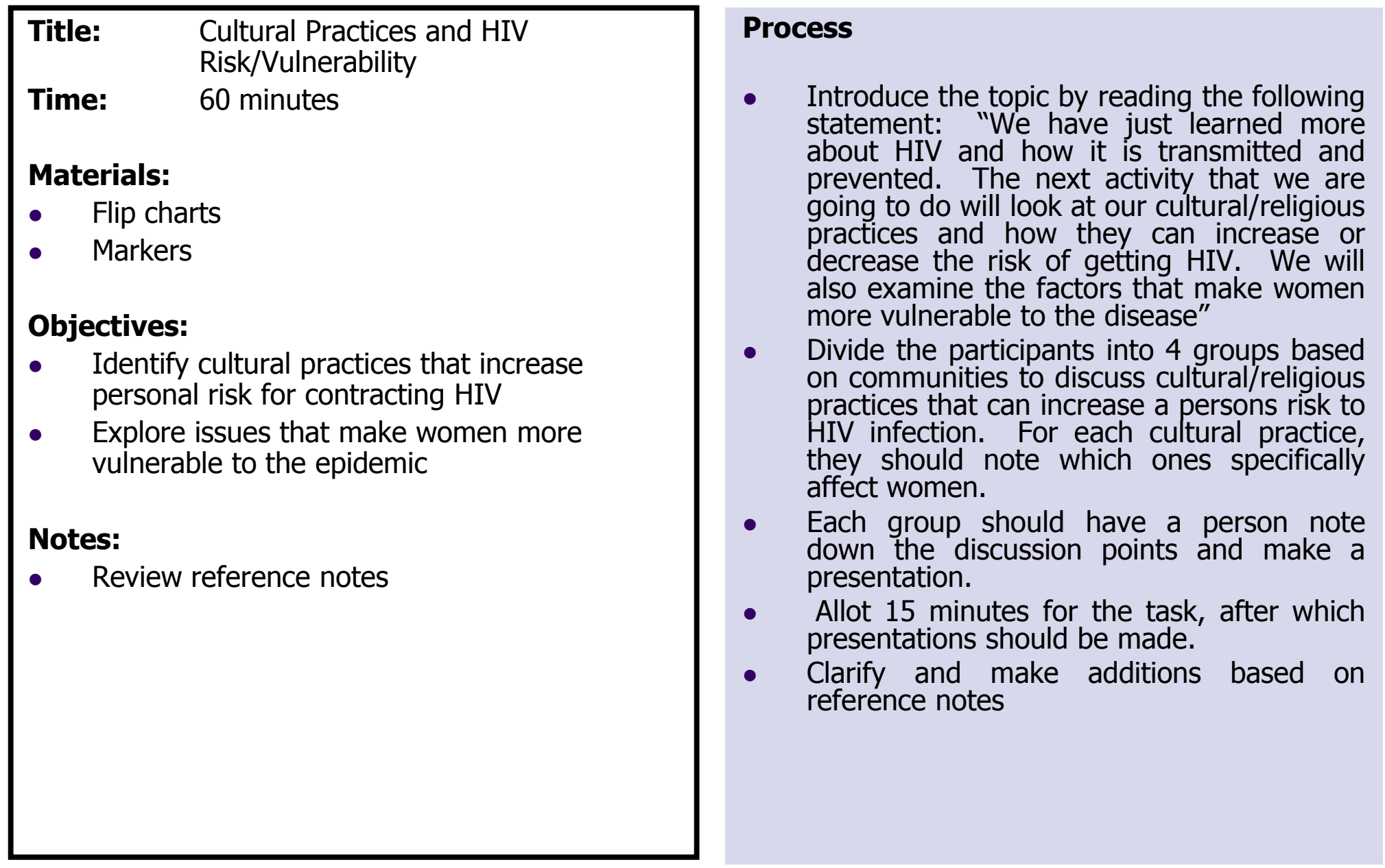




\section{Session 7: HIV Risks and Vulnerability}

\section{Process}

- Explain to participants the definition of vulnerability using reference notes.

- Using national and international statistics, discuss with participants women's vulnerability to the HIV/AIDS epidemic.

- Ask the participants to brainstorm factors that can make women more vulnerable to the epidemic.

- Note down the responses on flipchart.

- Facilitate a discussion about what males, including the community advocates, can do to address women's vulnerability to the epidemic. 
Session 8: VCT (Q4:28-32) "Allah desires to make clear to you, and guide you to, the path of those before you... Allah is AllKnowing, Wise; (Proverbs 11:14) "Where no counsel is the people fall; but in the multitude of counselors there is safety", (Proverbs4:7) "Wis dom is the principal thing; therefore get wisdom..."

Title: $\quad$ Voluntary Counseling and Testing
Time: $\quad 60$ minutes
Materials:
- $\quad$ Mlip charts
Objectives:
Define VCT
- $\quad$ Lxplain the concept of "Window Period"
$\quad$ couples before marriage
Notes:
Read the reference notes

\section{Process}

- $\quad$ Start by informing the participants that UNAIDS estimates that $90 \%$ of HIV infected people don't know they are HIV positive. People are still unaware that while scientists are trying to find a cure, the best form of defense is prevention.

- The only way HIV can be detected is when a person gets tested.

- $\quad$ Explain what the word VCT stands for

- $\quad$ Break the participants into 4 groups and they should brainstorm the reasons why people won't go for an HIV test.

- $\quad$ After the task, each group should present their results. Clarify and add any additional reasons.

- Remind the participants about the presentation on how the virus affects the body. Explain that the HIV test, actually tests for the antibodies in the blood. If there are antibodies found, the test will be positive, but if there are no antibodies found, it will be negative.

- $\quad$ Discuss the concept of window period and its implications for the test results with the participants. 
SesSIOn 8: VCT (Q35:28) "It is only those who have knowledge...that fear Allah..." A knowledgeable person is proud to know much and a wise person is humble that he knows no more; (Hosea 4:6a) "My people are destroyed for lack of knowledge"

\section{Process 2}

- $\quad$ Ask participants to brainstorm when they think voluntary testing is necessary. Flip chart/record responses.

- $\quad$ Possible responses should include: (1) if an individual is engaging in a behavior that might put them at risk such as having unprotected sex; (2) when a person is about to start a new sexual relationship and want to make sure that there is no risk of infection such as in the case of marriage; and (3) when a person wants to confirm HIV status because a sexual partner has been ill and has died of suspected AIDS related complications.

- Inform participants that how often a person gets tested depends on the situation. However it is advised that people should be tested every six months.

- Ask participants to break-up into their groups again and discuss the benefits to HIV testing

- $\quad$ The groups should present their results and discuss in plenary

- $\quad$ Summarize the session by stressing that it is very important to know one's status because it can be an entry point to providing care \& support and other services if the infection is detected on time. 


\section{Session 9: ARV and Positive Living}

hereafter and strives for it..." ; (Isaiah 55:11-12) "So shall my word be that goeth forth out of my mouth; it shall not return to me void but shall accomplish that which I please...", (Eccl 9:4a) "For to him that is joined to all the living there is hope..."

\section{Title: \\ Antiretroviral Drugs and Positive Living}

Time: $\quad 90$ minutes

\section{Materials:}

- $\quad$ Flip charts

- Markers

\section{Objectives:}

- $\quad$ Examine the functions and types of antiretroviral drugs available in Nigeria

- $\quad$ List the different types of OI and their treatment

- $\quad$ Describe the components of positive living

\section{Notes:}

- $\quad$ Review reference notes

- If possible, the session should be facilitated by a PLWHA with knowledge on positive living and treatment education.

\section{Process}

- Begin the session by reading the following statement: "Even though there is no cure for HIV, there are medications and things that a person living with HIV can do to live healthy productive lives and even prolong their lives. Most people think that knowing their HIV status is as good as a death sentence, but research advances have made it possible for many people living with HIV/AIDS to live normal and healthy lives. In this session we are going to learn about the medications and things that a PLWHA can do to stay healthy."

- Make a presentation on ARV using the reference notes and focus on (1) the classes of ARV, (2) its function in the body and (3) when to and steps taken to initiate ARV treatment.

- $\quad$ Stress that ARV is not a cure for HIV/AIDS but a drug to help manage the disease.

- Also include in the discussion issues of opportunistic infections and their treatment based on outline in the reference notes

- Allot 20 minutes for a PLWHA to share their experience and make a presentation on "positive living" using the outline in the reference notes.

- $\quad$ Round up by reflecting on the presentations and encourage participants to ask questions. 
Session 10: Stigma \& Discrimination (Q3:104) "Let there arise out of you, a band of people, inviting to all that is good, enjoining what is right..." (Hadith) "All Muslims are a single soul, if a limb in the body is ill other parts stand up in solidarity."

(1Peter 3:8, 10-11) "Finally be ye all of one mind having compassion one of another; love as brethren, be pitiful, be courteous; for he that will love life and see good days let him refrain his tongue from evil"

\begin{tabular}{|c|c|}
\hline $\begin{array}{l}\text { Title: } \quad \text { Stigma and Discrimination } \\
\text { Time: } \quad 60 \text { minutes } \\
\text { Materials: } \\
\text { - } \quad \text { Flip charts } \\
\text { - } \quad \text { Parkers } \\
\text { Objitive and negative labels } \\
\text { - Explives: } \\
\text { discrimination on lives of PLWHA } \\
\text { Identify key strategies for providing care \& } \\
\text { support for PLWHA } \\
\text { Notes: } \\
\text { - Review reference notes } \\
\text { - Prepare labels with negative words such as } \\
\text { "thief", "arm robber" and positive words such } \\
\text { as "beautiful", "hardworking" etc to correspond } \\
\text { with the number of participants in the } \\
\text { workshop. }\end{array}$ & $\begin{array}{l}\text { Process } \\
\text { - Inform the participants that to begin this } \\
\text { session, they are going to play a game } \\
\text { called "Who is Labeling Who" } \\
\text { Ask the participants to stand and greet } 5 \text { or } \\
\text { more people warmly as they would if they } \\
\text { meet for the } 1^{\text {st }} \text { time. } \\
\text { Then ask the participants to form a circle } \\
\text { and turn to the left hand side. Give each } \\
\text { person a card and masking tape without } \\
\text { letting them see what is written on the card. } \\
\text { Ask participants to stick the card they have } \\
\text { on the back of the person standing in front } \\
\text { of him/her. } \\
\text { Stress to the participants not to tell each } \\
\text { other what is written on their cards. } \\
\text { When everyone has a card attached to their } \\
\text { back ask them to move around and greet } \\
\text { each other as they did the first time, only } \\
\text { this time the type of greeting should depend } \\
\text { on the label on a person's back. For } \\
\text { instance, if you see a negative quality, they } \\
\text { should show their dislike by their expression } \\
\text { and movement and if they meet someone } \\
\text { with a positive quality they can show their } \\
\text { approval by interacting more with him/her. } \\
\text { After a few minutes ask the group to sit } \\
\text { down leaving their labels on. }\end{array}$ \\
\hline
\end{tabular}




\section{Session 10: Stigma \& Discrimination}

Q49:10) "The believers are nothing else than brothers

(in Islamic religion). So make reconciliation between your brothers, and fear Allah, that you may receive mercy" "A believer is a brother of a

believer, he should neither cheat him, nor disgrace him, forsake or reject him"; (Galatians 6:2) "Bear ye one another's burd ens, and so fulfill the law of Christ." (Luke 6:37) "Judge not and ye shall not be judged; condemn not and ye shall not be condemned; forgive and ye shall be forgiven"

\section{Process}

- Ask for volunteers to talk about their experiences using the discussion questions as a guide.

- Facilitate a brainstorming session where participants should list ways to provide care \& support to PLWHA

- $\quad$ End the session by reminding participants that there are several obstacles a PLWHA may go through. Stigma and discrimination against PLWHA doesn't allow them to tell people that they are HIV positive. State that in order to live positively the PLWHA needs care from community members and family members.

- Also stress that because of stigma and discrimination many people do not want to find out their status. This then increases the spread of HIV.

\section{Discussion Questions}

1. How did you feel during the first greetings?

2. How did you feel during the second greetings?

3. Did others treat you differently? why?

4. How did that make you feel? Write the response on the flip chart.

5. Did you treat others differently? How?

6. What have we learned from this exercise?

7. How do you feel being labeled the way you were?

8. How can we relate this to what happens in the community with people living with HIV/AIDS?

9. How are women living with HIV/AIDS treated in the community?

10. Is this different from the way men living with HIV/AIDS are treated? Why?

11. How should we actually treat PLWHA in our community? 


\section{Session 11: Sexually Transmitted Infections}

\section{Title: \\ Sexually Transmitted Infections}

Time: $\quad 60$ minutes

\section{Materials:}

- $\quad$ Flip charts

- Markers

\section{Objectives:}

- Identify the different types of STI

- $\quad$ Explore the effects of untreated STI

\section{Notes:}

- $\quad$ Review reference notes

\section{Process}

- Begin the session by explaining what the acronym STI stands for and share a definition with the participants.

- $\quad$ Break the participants into small working groups and ask them to list out common STIs and possible effects.

- After completion of task, presentations should be made.

- Using the reference notes, go through each type of STI and its symptoms

- At the end of the presentation, review with the participants the common signs and symptoms of STIs.

- $\quad$ Highlight the fact that most women do not manifest signs when infected with STIs

- Discuss the relationship between STI and HIV transmission

- Conclude by asking participants what should be done if someone suspects that $\mathrm{s} /$ he is infected with an STI.

- Also mention the importance of partner notification in helping to reduce the rates of STI. 
Session 12: Birth Spacing (Q2:233) "And we have enjoined on man to be good and dutiful to his parents. His parents bring him forth with hardship..." ; (1Corinthians 14:40) "Let all things be done decently and in order."

Title: $\quad$ Family Planning/Birth Spacing

Time: $\quad 90$ minutes

\section{Materials:}

- $\quad$ Flip charts

- Markers

- $\quad$ Sample of Birth Spacing methods

\section{Objectives:}

- Explore common misconceptions \& myths about family planning

- Identify the barriers and benefits of birth spacing

- $\quad$ Describe the various types of birth spacing methods

\section{Notes:}

- $\quad$ Review reference notes

- Use anatomy diagram in explaining how the methods work

\section{Process}

- $\quad$ Begin the session by asking participants to brainstorm things they have heard about family planning/birth spacing, these should include things they think are true or false. Flip chart/record responses.

- $\quad$ Go through the participants response and clarify the myths and misconceptions

- Ask for volunteers to provide definition for birth spacing and flip their response. Harmonize using the definition in the reference notes

- $\quad$ Break the participants into four groups. Two groups should list some of the barriers couples face in using birth spacing and the other 2 groups to explore the benefits of birth spacing

- Allot 15 minutes for the assignment and the groups should make their presentations in plenary.

- $\quad$ Summarize the presentation by making additions to their responses if necessary.

- $\quad$ Ask in plenary for participants to identify strategies of counteracting the barriers to birth spacing. Flip chart/record the responses. 
Session 12: Birth Spacing $(Q 46: 15)$ "...And she brings him forth with hardship and his conception and weaning of him is thirty months." ; (Psalms 127:3) "Lo children are an heritage of the Lord; and the fruit of the womb is his reward"

\section{Process 2}

- Go over each method, highlighting the way it works, the advantages and disadvantage of each method.

- Show participants samples if they are available, if not show pictures.

- Use anatomy diagrams to explain the process of how each method works if needed.

- Allot 10 minutes for questions from participants after review of the methods 
Session 13: Safe Motherhood (Q5:2) "...help ye one another in righteousness and pity..." ; (Isaiah 41:10) "Fear thou not for I am with thee..."

Title: $\quad$ Safe Motherhood
Time: $\quad 60$ minutes
Materials:
- $\quad$ Flip charts
- $\quad$ Markers
"Steps to healthy pregnancy" handout
Objectives:
- Identify the components of safe
motherhoods
Identify the challenges to actualizing safe
motherhoods
List possible strategies for improving
maternal and child health
List the steps to a healthy pregnancy
Notes:
Review reference notes.
Mass produce notes on "steps to healthy
pregnancy"

\section{Process}

- Introduce the topic of safe motherhood by reviewing maternal mortality statistics with the participants based on the reference notes.

- $\quad$ Paste flip chart with definition of safe motherhood and discuss with group

- Break the participants into three groups. Each group should list the things a mother needs to do to be healthy and have a health baby during each of the following stages (1) During Pregnancy; (2) Delivery; (3) After Delivery.

- Allot 15 minutes for the task. Each group should make their presentation and clarification should be made using the reference notes, discussing each of the components of safe motherhood.

- In plenary, participants should brainstorm the barriers or challenges to safe motherhood in their communities.

- $\quad$ For each challenge, participants should also mention possible strategies for addressing the challenges.

- $\quad$ Round up the discussion by reading through the "Steps to a Healthy Pregnancy" sheet with the participants.

- Remember to discuss the delays in safe motherhood. 
Session 14: Gender Roles (Q4:34) "...believing men are the protectors, maintainers and supporters of their wives..." ; (Galatians 3:27-28) "...there is neither male nor female for you are all one..." , (Genesis 1:27) "So God created man in his own image...man and woman created he them"

Title: $\quad$ Gender Roles in the Family

Time: $\quad 60$ minutes

\section{Materials:}

- $\quad$ Flip charts

- Markers

\section{Objectives:}

- Define gender and sex

- Examine how gender affects roles in the family and community

- Explore how gender roles enhances/limits an individual's choices

\section{Notes:}

- $\quad$ Review reference notes

- $\quad$ Prepare flip charts based on reference notes

\section{Process}

- $\quad$ Begin the session by asking the participants to think about the first time that they became aware that boys and girls are treated differently in their family or community.

- Break the participants into 4 groups and ask them the role play one memory and present the role play in plenary.

- Facilitate a discussion using the discussion questions.

- Facilitate a discussion on the role of women/men in various religionsChristianity/Islam depending upon the group's profile.

- Ask the participants to brainstorm the difference between the terms gender and sex.

- $\quad$ Flip chart/record responses and provide clarifications using the reference notes.

- $\quad$ Read the poem "Nine tears of sorrow". Ask the participants to image what it would feel like to be the girl who wrote the poem.

- The participants should discuss and reflect on some of the issues highlighted in the poem, relating it to other sessions conducted. 
Session 14: Gender Roles (Q23:8) “... who are faithfully true to their Amanat...”; (Matt 15:3)

"...why do ye also transgress the commandments of God because of your tradition"

\section{Nine Tears of Sorrow}

When my mother gave birth to me, nine tears of sorrow were shed.

1. When my brothers were born, special drums of joy were beaten

2. My brother goes to play while I sweep and wash the clothes

3. My brothers gets his food first and drinks milk, while i sit and watch

4. My brother goes to school while I do the house chores

5. My brother goes to college and gets a higher degree and now has a good job.

6. I turned 12 and was married off

7. I have 4 children and fall sick a lot

8. My mother-in-law and sisters-in-law want to have additional hands for the house work and have told my husband to marry again

9. I appeal to all my sisters not to have their child marry early, but to educate their daughters well.

\section{Discussion Questions.}

- What were the men and boys like in the role-play?

- What were the women and girls like?

- In what ways are boys and girls treated differently within the family and community?

- What benefits do boys/men get from being treated differently?

- What benefits do girls get from being treated differently?

- What disadvantages do girls experience from this different treatment?

- What differences do you think we are born with?

- What differences do we learn and how do we learn them? 
Session 15: Early Marriage (Q4:6)"And try orphans as regards their intelligence until

they reach the age of marriage...; (Ecclesiastes 3:1) "To everything there is a season and a time to every purpose under the heaven" (Ecclesiastes 3:11) "He hath made everything beautiful in his time."

\begin{tabular}{|c|c|}
\hline $\begin{array}{l}\text { Title: } \begin{array}{l}\text { Community's Views of } \\
\text { Marriage and its } \\
\text { consequences. }\end{array} \\
\text { Time: } \quad 90 \text { minutes } \\
\text { Materials: } \\
\text { - } \quad \text { Flip Chart } \\
\text { - } \quad \text { Storkers } \\
\text { Objectives: } \\
\text { - } \quad \text { Explore the views of marriage } \\
\text { from various cultures and religion } \\
\text { Identify factors that influence the } \\
\text { early marriage of girls } \\
\text { List the impact of early marriage } \\
\text { on young girls }\end{array}$ & $\begin{array}{l}\text { Process } \\
\text { - Begin the session by telling the participants that } \\
\text { the next session is going to look at them and } \\
\text { the community's views about marriage. } \\
\text { Divide the participants into small groups based } \\
\text { on community or religious affiliation. } \\
\text { In the small working groups, they should } \\
\text { discuss and present in plenary male and female } \\
\text { perceptions of marriage within their } \\
\text { cultural/religious context. } \\
\text { After presentation, facilitate a discussion on } \\
\text { factors that influence the early marriage of girls } \\
\text { in their community. } \\
\text { Upon completion of the discussion, read out } \\
\text { loud Hauwa's story and facilitate a discussion } \\
\text { using the guide. } \\
\text { Break participants into small working groups } \\
\text { and ask them to explore the social, emotional } \\
\text { and physical impact of early marriage on } \\
\text { females. } \\
\text { Divide each type of impact amongst the groups } \\
\text { and presentations should be made in plenary } \\
\text { The facilitator should make additions to } \\
\text { presentations and clarify issues/questions } \\
\text { The session should be concluded with a } \\
\text { discussion, participants should reflect on the } \\
\text { situations in their community to determine if } \\
\text { there is evidence of the impact. }\end{array}$ \\
\hline
\end{tabular}


Session 15: Early Marriage

\section{Child Marriage: The case of Hauwa Abubakar}

A famous ruling by the high court of Kaduna upheld the right of a father to "compel his virgin daughter into marriage without her consent and even if she has not obtained puberty", supposedly in line with the Maliki School of Islamic law, which had been invoked in the lower court. One such virgin daughter was Hauwa Abubakar whose gruesome murder made headlines in 1987. At the age of nine, her father married her off to one Mallam Shehu Garba Kiruwa, a 40 year-old cattle dealer to whom he owed money. For two years she refused to go and live with her putative husband, but she was taken to his house when she began to menstruate at the age of twelve. Still not content to accept her lot, she twice ran away and was twice forcibly returned. On the third occasion, Mallam Shehu pinned her down and chopped off her legs with a poisoned cutlass, resulting in her death.

\section{Discussion Guide}

- Is the story of Hauwa common in our community?

- What do you think about Hauwa's situation?

- How would you describe the feelings that Hauwa might have had?

- What were some of the effects of early marriage on Hauwa's life?

- What can be some factors that were influencing Hauwa's marriage?

- Reflecting on our sessions on HIV transmission and risk, what are some possible HIV/AIDS risk factors in this story?

- What can we do as community advocates to address the issue of early marriage in our community? 
Session 16: Gender Based Violence (Q4:19) "... o you who believe! You are

forbidden to inherit women against their will; and you should not treat them with harshness... " ; (1Peter 3:7)

"Likewise, ye husbands, dwell with them according to knowledge, giving honor unto the wife."

\begin{tabular}{ll|}
\hline Title: $\quad$ Gender Based Violence \\
Time: $\quad 90$ minutes \\
Materials: \\
- $\quad$ Flip charts \\
- $\quad$ Harkers \\
Objectives: \\
Define Gender Based Violence \\
Identify the various forms of Gender Based \\
Violence \\
Examine the causes/factors that influence \\
the prevalence of Gender Based Violence in \\
Northern Nigerian communities \\
Explore the relationship between Gender \\
Based Violence and HIV risks/vulnerability \\
Notes: \\
Review reference notes \\
\end{tabular}

\section{Process}

- $\quad$ Begin the session by asking participants to share their definition on what the following terms: (1) Violence and (2) Gender Based Violence.

- $\quad$ Introduce the topic by presenting a standard definition for gender based violence.

- $\quad$ Divide participants into small groups and ask them to discuss what acts/actions they would consider to be gender based violence.

- $\quad$ Assign 20 minutes for the task, after which presentations should be made in plenary. Harmonize the responses provided into one list.

- Include any omissions and use the reference notes to provide a detailed presentation on the various forms of gender based violence. Also include female genital cutting in the discussion

- In plenary, discuss with participants if such acts/issues are present in their communities and what factors cause/influence the various forms of gender based violence. Note down the responses.

- $\quad$ Read the story of Hassana and facilitate a discussion using the discussion questions. 


\section{Session 16: Gender Based Violence}

\section{Process Continued}

- Discuss the issue of male/female power dynamics and rights.

- $\quad$ Divide the participants into small groups and ask them to discuss how the forms of gender based violence can increase women's risk/vulnerability to HIV.

- Upon completion of the task, the groups should make their presentations in plenary.

- To conclude the session, take the participants through a round robin. Each participant should brainstorm actions they as advocates can take to reduce the occurrences of gender based violence in their community.

\section{Discussion Questions.}

- How do you feel about the story?

- Is this type of scenario common in our communities?

- What are some of the forms of GBV in this scenario?

- Does Hassana have the right to refuse her husband sex? ( Back your answers with quotations from the Quaran)

- Would you consider what her husband did as rape? Why?

- $\quad$ Did the husband have the right to beat her?

- Did Hassana have any control over the situation?

- What strategies could have been applied to resolve the situation from Hassana and her husband?

\section{Hassana' Scenario}

Hassana is the last of 3 wives and she currently has only one child. Her husband has been unhappy with her for the past 4 months. The last time he spoke to her he said: "Since I married you, you have been no use to me, only to collect money every time. If you are not willing to perform your wifely duties, neither will I". Hassana begged him for forgiveness but he did not give her feeding allowance for the month. How can she tell him that every time they have sex she experiences a lot of pain due to the cutting from her circumcision. She faced a lot of difficultly with her pregnancy because of the situation. Two days later, when it was her turn, she tried to explain the problem but he didn't listen to her. Instead he began to beat her with his belt and forced her to have sex. The experience was very painful and afterwards she was bleeding for the next three days. He refused to let her go outside, even to seek medical assistance. The other wives are happy because he buys them lots of gifts and not her. They have asked him to divorce her since she is of no use to anyone. 


\section{Session 17: Couple Communication}

Title: $\quad$ Couple Communication
Time: $\quad 60$ minutes
Materials:
- $\quad$ Flip charts
- $\quad$ Storkers of Fatima
Objectives:
- $\quad$ Explore causes of conflict amongst married
couples
Examine consequences of non-
communication
Identify strategies for promoting couple
communication
Notes:
The participants should be encouraged to
identify the issues as they relate to their
individual communities.

\section{Process}

- $\quad$ Begin the session by asking participants to brainstorm common causes of conflict amongst married couples in their communities. Flip chart/record responses

- Read the story of Fatima to the group.

- $\quad$ Facilitate a group discussion on the story using the discussion questions

- $\quad$ Ask participants to break into small groups and provide a role-play featuring a positive alternative to the story.

- $\quad$ Role-plays should be presented in plenary and positive aspects of the presentations should be identified and discussed with the participants.

- Brainstorm with the participants some of the barriers to couple communication in their communities.

- Also brainstorm the benefits of couple communication.

- $\quad$ Flip chart/record responses and make additions to omitted issues.

- $\quad$ Conclude the session by discussing how couple communication can be improved and what the participants can do as community advocates to encourage communication between couples, especially young couples. 


\section{Session 17: Couple Communication}

\section{Fatima's Story}

At 5pm, Fatima comes home tired from her work as a market trader everyday. She starts preparing food for her husband, Usman immediately she arrives. He usually comes home around 5:30p.m. and wants to eat at $6 \mathrm{pm}$. On this day Usman comes home early with two of his friends from work and leaves immediately without telling Fatima.

Fatima finishes cooking and waits for Usman until $10 \mathrm{pm}$. She eventually goes to bed after waiting for so long. Usman gets home at $11 \mathrm{pm}$, turns on the lights and demands for his food. Fatima rolls over half asleep and Usman shakes her demanding his food. She mumbles that she needs to sleep in order to get up by $5 a . m$ the next day. Usman shouts at her to get his food and eventually he removes his belt and starts beating Fatima. Fatima wakes up to the beating, sobbingly she gets up to get Usman's food.

\section{Discussion Questions.}

- What are some of the problems in this scenario?

- What are some of the communication problems?

- Is there respect amongst the couple?

- In what ways was Usman showing lack of respect for Fatima

- What would have been the best way to resolve the issues?

- How can Fatima and Usman improve their communication? 


\section{Module Overview}

\section{Module 4: Advocacy Skills}

This module is the skills based component of the manual. Participants will learn the basic skills needed to carry out advocacy activities. The technique applied in this module is primarily roleplays with a few short presentations.

$\begin{array}{lll}\text { Session 1 } & \text { Communication - Muddling Messages } & 20 \text { mins } \\ \text { Session 2 } & \text { Communication - Listening Pairs } & 30 \text { mins } \\ \text { Session 3 } & \text { Communication - Body Language } & 40 \text { mins } \\ \text { Session 4 } & \text { Overview of Communication } & 40 \text { mins } \\ \text { Session 5 } & \text { Overview of Negotiation } & 60 \text { mins } \\ \text { Session 6 } & \text { Lobbying/Face to Face Meeting } & 60 \text { mins } \\ \text { Session 7 } & \text { Facilitating Discussions } & 60 \text { mins } \\ \text { Session 8 } & \text { Making Presentations } & 60 \text { mins } \\ \text { Session 9 } & \text { Presenting a Drama } & 60 \text { mins } \\ \text { Session 10 } & \text { Conducting a Media Interview } & 60 \text { mins } \\ \text { Session 11 } & \text { Effective Referrals } & 50 \text { mins }\end{array}$

Total Module Time: 9 hours (540 minutes) 


\section{Session 1: Communication}

\section{Title: $\quad$ Muddling Messages}

Time: $\quad 20$ minutes

\section{Materials:}

- $\quad$ None

\section{Objectives:}

- Introduce the concept of communication

- Illustrate how easy it is to misunderstand people

\section{Notes:}

- This is a warm-up exercise that can also serve as an icebreaker if this is the $1^{\text {st }}$ session of the day.

- $\quad$ Statements should be simple and can be relevant to their community work

\section{Process}

- $\quad$ Tell the participants that they are going to play some games before beginning the session.

- Think of a statement and whisper it to the next person sitting to the facilitator's right hand.

Examples could be

"We are going to finish this session and go to the community to dance and celebrate with all our friends and families to show our joy for the completion of the training."

- $\quad$ Ask the person to whisper the statement quietly to the next person and the statement should be passed around, one at a time to all the participants.

- When the last person in the circle has been told the statement, ask him/her to say it out loud to the group.

- $\quad$ Ask the $1^{\text {st }}$ participants that you told the statement to repeat what was said to him/her.

- $\quad$ Ask the participants to make comparison between the two statements

- $\quad$ Round up by asking what was the purpose of the activity and the importance of communication 


\section{Session 2: Communication}

\section{Title: $\quad$ Listening Pairs}

Time: $\quad 30$ minutes

Materials:

- $\quad$ None

\section{Objectives:}

- Illustration of the importance of listening skills for good communication

- Examine components of good listening skills

\section{Notes:}

- $\quad$ Make sure that the talking group doesn't hear the instructions being given to their partners.

- $\quad$ Refer to notes for elements of good listening skills

\section{Process}

- Inform the participants that in the workshop and in our work, they would have to do a lot of listening. The next activity is going to examine the elements of good listening skills

- $\quad$ Divide participants into pairs. Assign the roles of listener and talker to each of the pairs.

- $\quad$ Pulling the listeners aside, inform them without the others knowing that they should pay attention to their colleagues for at least 2 minutes. After 2 minutes, they should behave as if they are distracted by moving in their seats, playing with something on their table, stop making eye contact. Any behavior that would show that they are apparently distracted and not paying attention.

- $\quad$ Ask them to return to their seats and the talkers should share a story about their lives to their partner.

- $\quad$ After a few minutes ask the groups to stop and ask for volunteers from the talkers to share their experiences.

- Brainstorm with participants elements of good listening skills and flip chart/record responses.

- $\quad$ Conclude the session by discussing the importance of listening in communication 


\section{Session 3: Communication}

\begin{tabular}{|c|c|}
\hline Body Language & Process \\
\hline $\begin{array}{l}\text { Time: } 40 \text { minutes } \\
\text { Materials: } \\
\text { None } \\
\text { Objectives: } \\
\text { - Illustrate the role of body language in } \\
\text { communication } \\
\text { Notes: } \\
\text { Make sure that the talking group } \\
\text { doesn't hear the instructions being } \\
\text { given to their partners. } \\
\text { Refer to notes for elements of good } \\
\text { listening skills }\end{array}$ & $\begin{array}{l}\text { - Inform the participants that the next session } \\
\text { is still examining the issues of } \\
\text { communication, because of its importance to } \\
\text { their work. } \\
\text { Ask for a volunteer to come and tell the } \\
\text { facilitator about how they feel about the } \\
\text { workshop thus far. } \\
\text { Seated in the center of the room, the } \\
\text { facilitator should demonstrate several } \\
\text { negative body languages that can make the } \\
\text { volunteer feel uncomfortable. } \\
\text { Repeat with another participant } \\
\text { demonstrating positive body language } \\
\text { Ask the group to mention what they } \\
\text { observed with the discussions. They should } \\
\text { brainstorm what kinds of emotions were } \\
\text { demonstrated through the body language in } \\
\text { both situations } \\
\text { Flip chart/record their responses } \\
\text { Ask for a volunteer to explain the } \\
\text { relationship between the types of body } \\
\text { language and communication. } \\
\text { Summarize the discussion by clarifying the } \\
\text { role of body language in communication. } \\
\text { Specify how the body language can foster or } \\
\text { hinder communication }\end{array}$ \\
\hline
\end{tabular}




\section{Session 4: Communication}

\section{Title: Overview of Communication}

Time: $\quad 40$ minutes

\section{Materials:}

- $\quad$ Flip Charts with notes on definition of communication, elements of effective communication and barriers to effective communication

\section{Objectives:}

- Define communication

- Identify elements of effective communication

- Identify the barriers in effective communication

\section{Notes:}

- Review notes in the reference section

- $\quad$ Prepare flip charts with notes for presentations at the end of the session

\section{Process}

- Inform the participants that they have explored some components of communication. This session is going to bring together all the lessons they have gained from the previous sessions.

- $\quad$ Ask for volunteers to define communication. Flip chart/record responses for every volunteer.

- $\quad$ Present a sample definition to harmonize participants' definition.

- Break the participants into two groups, one group should discuss/present aspects of effective communication and the other group barriers to effective communication.

- Assign 10 minutes for the task and the groups should present their tasks.

- $\quad$ Conclude the session by reviewing their presentations, adding omitted elements for both task.

- Make presentation to the participants using lecture notes

- $\quad$ Allocate 10 minutes for additional questions from participants 


\section{Session 5: Negotiation}

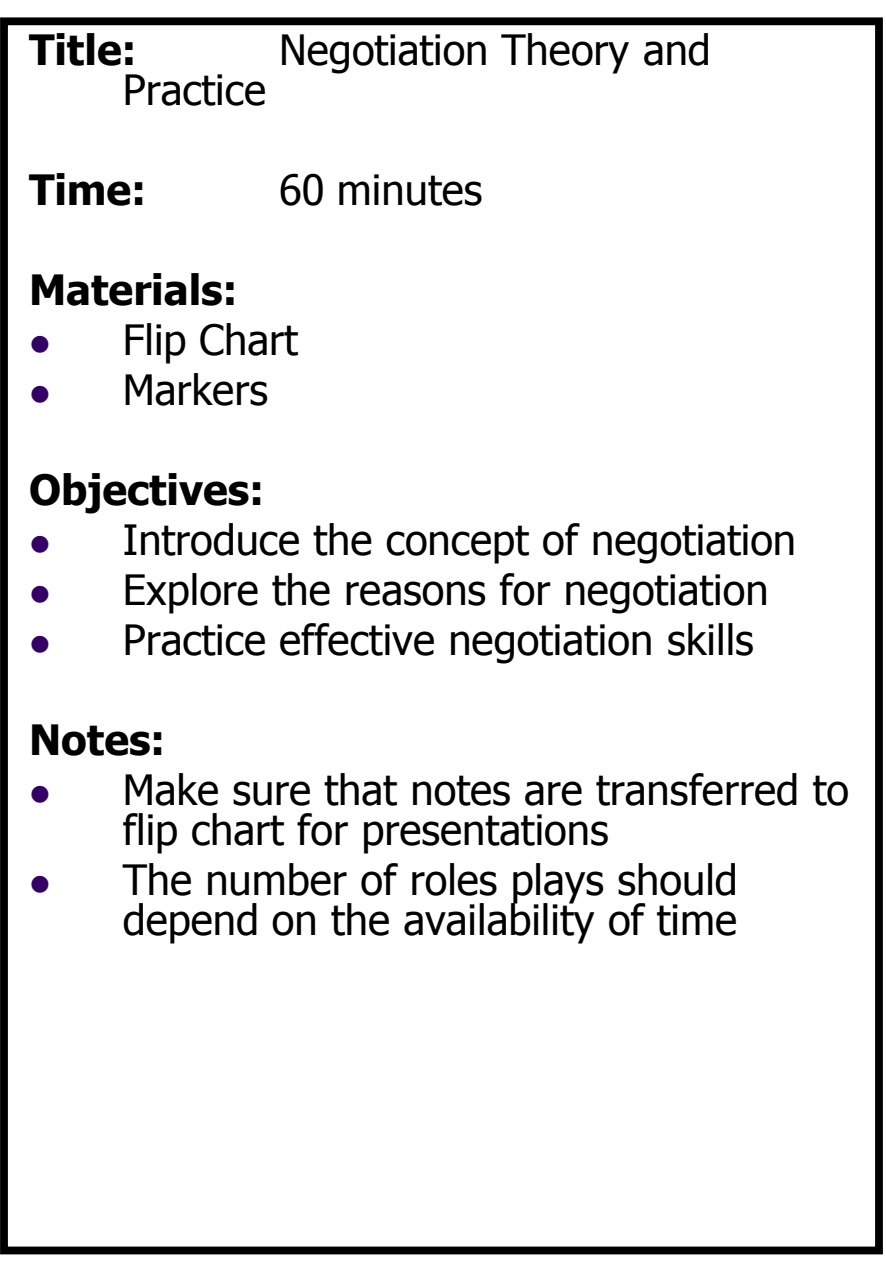

\section{Process}

- Introduce the topic by reading the statement:

"Negotiation is very important in our various interactions with people. We negotiate with our spouse, children, community leaders and political leaders all the time. We even negotiate when we go to the market to buy food".

- $\quad$ Ask for volunteers to define negotiation, flip chart/record responses. Clarify points by presenting definition on flip chart using reference notes

- $\quad$ Ask participants to think about how negotiation will enhance their work as community advocates. Flip chart/record responses.

- Make presentation of the skills for negotiation using notes in the reference and allocate 10 minutes for questions from participants

- $\quad$ Review the use of "I" statements with participants

- $\quad$ Distribute role plays and ask for volunteers to act it out using the negotiation skills. Ask others to note down strengths and weakness

- Conclude the session by discussing challenges and how negotiations skills can be improved with practice. 


\title{
Session 5: Negotiation
}

\author{
Case Study \\ \#1: \\ You have been approached by an angry group \\ of people in the community. They have accused \\ you of spreading a Western culture on birth \\ spacing. They are screaming and abusing you. \\ What do you do? \\ \#2: \\ You are making a presentation on the need to \\ support and care for people living with \\ HIV/AIDS. In the middle of your presentation, \\ some persons in the crowd oppose you and \\ begin to condemn all people living with \\ HIV/AIDS
}




\section{Session 6: Lobbying}

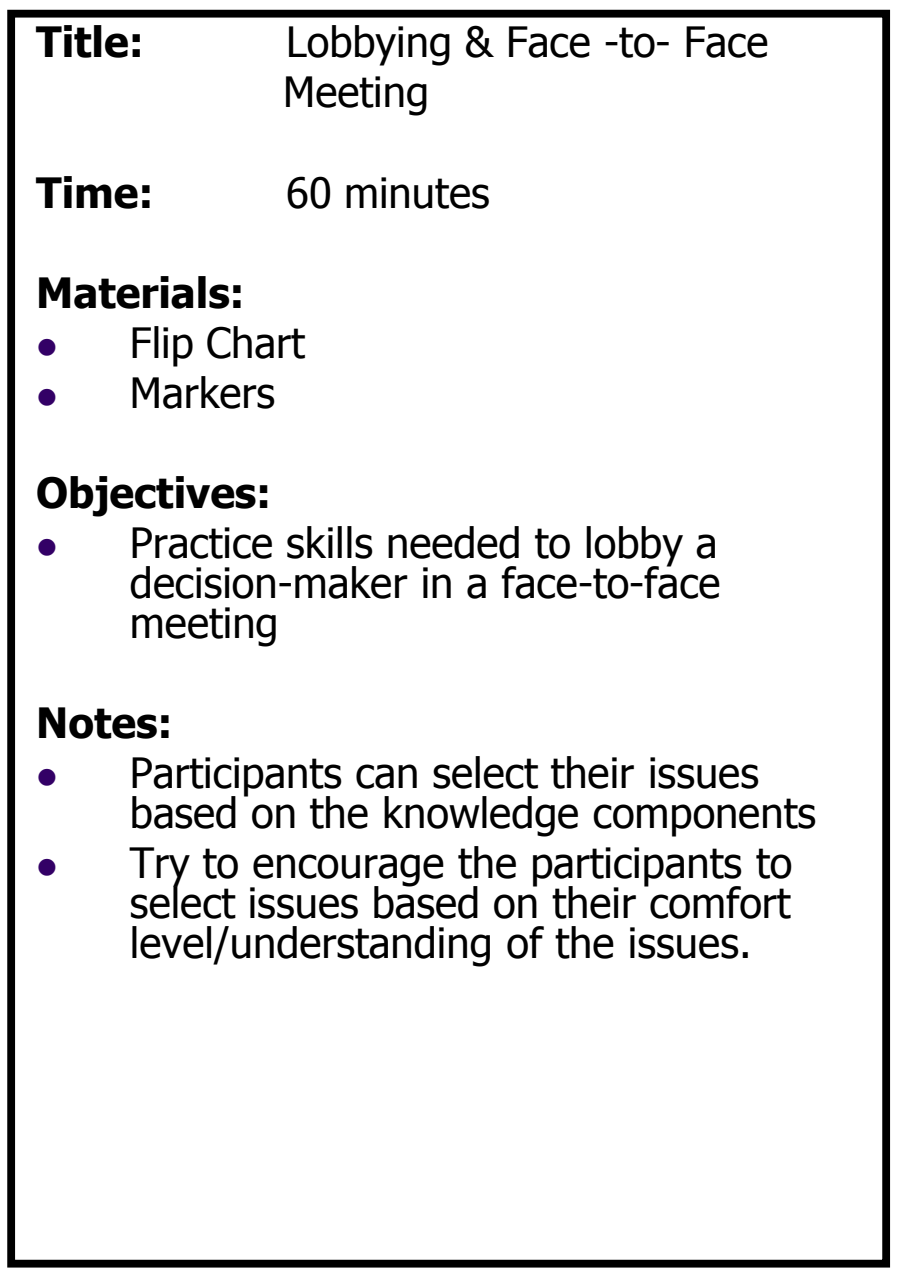

\section{Process}

- Introduce the topic and explain to participants that they will practice an advocacy skill called lobbying.

- Ask participants what are the advantages and disadvantages of holding face-to-face meetings with decision makers for advocacy work?

- Divide the participants up into small groups of four to six people, 1 person as the decisionmaker and the others as the advocates. Assign to the groups different topical issues.

- $\quad$ Ask at least one group to role-play a 10 minute meeting in which the decision-maker opposes the advocacy issue and another group to role-play a meeting in which the decision-maker is neutral or uninterested in the advocacy issue.

- $\quad$ Give each group these guidelines: (1) prepare your case with facts and evidence to support what you will say; (2) identify what the decision-maker might say, and plan your replies (3) consider how you want to behave during the meeting and why and (4) decide what, if anything, you should take to the meeting. 


\section{Session 6: Lobbying}

\section{Process 2}

- $\quad$ Allot 10 minutes for the advocates to prepare and the role-play which will be performed in plenary

- After both plays, lead a discussion about the meetings based on the following questions:

(1) Who was more persuasive and why?

(2) How could the advocates have improved their lobbying?

(3) How might you follow-up a face-to-face meeting?

(4) What did you learn about face-to-face meetings from the role-plays?

(5) What are the advantages of having people directly affected by the issue or problem at such a meeting?

- Conclude the session by encouraging any other comments or experiences of face to-face advocacy. 


\section{Session 7: Facilitation}

Title: $\quad$ Facilitating Discussions
Time: $\quad 60$ minutes
Materials:
- $\quad$ Flip Chart
Markers
Objectives:
- Examine the qualities of a good
facilitator
Identify the roles of a facilitator
Practice facilitation skills to be used for
community dialogue and IPC session
Notes:
Create a presentation using lecture
notes on the roles of a facilitator
Transfer notes on the qualities of a
good facilitator onto flip chart ahead of
time

\section{Process}

- Introduce the concept of facilitation by asking participants to define it, taking note of the things that the training facilitators have done since the beginning of the workshop. Flip chart/record responses

- Harmonize responses and tell participants that as advocates they might have to facilitate group discussions on various issues. Stress that facilitation is not an advocacy method, but a tool that can significantly enhance advocacy activities.

- Ask participants to brainstorm qualities of a good facilitator and flip chart/record responses.

- Inform participants that the role of a training facilitator is different from a community dialogue facilitator. Ask them to list out the roles of a community dialogue facilitator, flip chart/record responses

- Make clarification using presentation from lecture notes

- $\quad$ Ask for 2 volunteers to facilitate a community dialogue on the topic: Early marriage - Its consequences. 


\section{Session 7: Facilitation}

\section{Process 2}

- $\quad$ Ask for 2 volunteers to facilitate a community dialogue on the topic: Early marriage $\&$ Its consequences.

- $\quad$ Other participants should take notes and provide feedback on what went well and what needs improvement.

- $\quad$ Assessment should be based on brainstormed qualities of a facilitator and the role of a facilitator.

- $\quad$ After the feedback session, the facilitator should also comment on the positives and areas of improvement

- $\quad$ The session should be concluded by reassuring the participants that facilitation skills are developed over time. And they would have other opportunities in the workshop to practice these skills.

- $\quad$ Remind the participants that facilitation is not an advocacy method but a tool to be used with methods such as presentations, community dialogue, interpersonal communication session, and "processing" after a drama presentation. 


\section{Session 8: Presentations}

\section{Title: $\quad$ Delivering Presentations}

Time: $\quad 60$ minutes

\section{Materials:}

- $\quad$ Flip chart

- Marker

\section{Objectives:}

- $\quad$ Practice the skills of developing and delivering a simple presentation

\section{Notes:}

- $\quad$ Encourage participants who have not taken part in any group work or practical sessions to make presentations

- $\quad$ Document the "qualities of successful presentations" brainstormed and mass produce for participants as part of their handouts

- Encourage positive feedback as well as suggestions for improvement.

\section{Process}

- Inform the participants that this session will look at the skills of presentation. Remind them that throughout the workshop, the facilitators have made presentations on several topics and this technique can be used to persuade influential persons in groups about advocacy issues.

- $\quad$ Brainstorm with participants on the qualities of the presentations they like and learned most from. Flip chart/record these responses under the title "qualities of successful presentations" and place where all can see them.

- $\quad$ Divide the participants into groups of 4 people each to prepare a 5 minute presentation on an advocacy issue (possibly an issue already discussed in the workshop) for the whole group.

- Each group should decide which member or if the entire group members will deliver parts of the presentation

- Stress that they should include some of the good qualities of the presentations they have identified. 


\section{Process 2}

- $\quad$ Ask a number of groups to deliver their presentations to the whole group

- $\quad$ Ask for feedback for each presentation, based on the following questions:

(1) Was the message clear?

(2) Was their presentation convincing?

(3) Did the presentation incorporate some of the elements of successful presentations?

(4) What was the best aspect of the presentation?

(5)What can be improved?

- $\quad$ Ask for participants to discuss their experiences of delivering presentations, especially as part of advocacy work

- $\quad$ Conclude the session by commending the efforts of all the presenters and reassure them that with more practice, their presentation skills would improve. 


\section{Title: \\ Organizing a Drama}

Time:

60 minutes

\section{Materials:}

- None

\section{Objectives:}

- $\quad$ Plan and perform a simple drama to serve as an advocacy tool.

\section{Notes:}

- Encourage quiet participants to take part in the dramas to boost self confidence

- $\quad$ Remind participants of the skills learned during the session on facilitation

- $\quad$ Encourage participants to think of a powerful story to portray the issue, it could even be based on a true story

\section{Process}

- Tell the participants that drama is usually associated with information, education and communication (IEC) more than advocacy. It becomes an advocacy method when the general public has been identified as an 'indirect target' who will go on to influence a direct target. For example, traditional council members who will influence the chief; or when influential people are in the audience. Drama can be a very effective way of involving the people affected by the advocacy issue.

- Divide participants into groups of four or five people and give participants 20 minutes to plan a 5 minute drama.

- As part of their discussions, they should identify and note down the following:

(1) An advocacy issue or problem;

(2) The result they want after the advocacy has been conducted ;

(3) A target audience of influential people; and

(4) Discussion questions they will use with their audience and a facilitator that would lead the discussion 


\section{Session 9: Drama}

\section{Process 2}

- $\quad 2$ groups should perform their plays and facilitate a follow-up discussion

- $\quad$ After the performances and discussion, the workshop facilitator should lead discussion with participants based on the following questions

(1) What was the message passed in the drama?

(2) What did you like about the dramas?

(3) What could be improved?

(4) How was the facilitation of the discussion?

(5) What do you think the reaction would be from the real target audiences of these dramas?

(6) Why is it important to have a discussion after a performance?

(7) What is different about drama, compared to other advocacy methods?

- $\quad$ Conclude the session by asking for participants to share comments or experiences of using drama for advocacy. 


\section{Session 10: Media Interview}

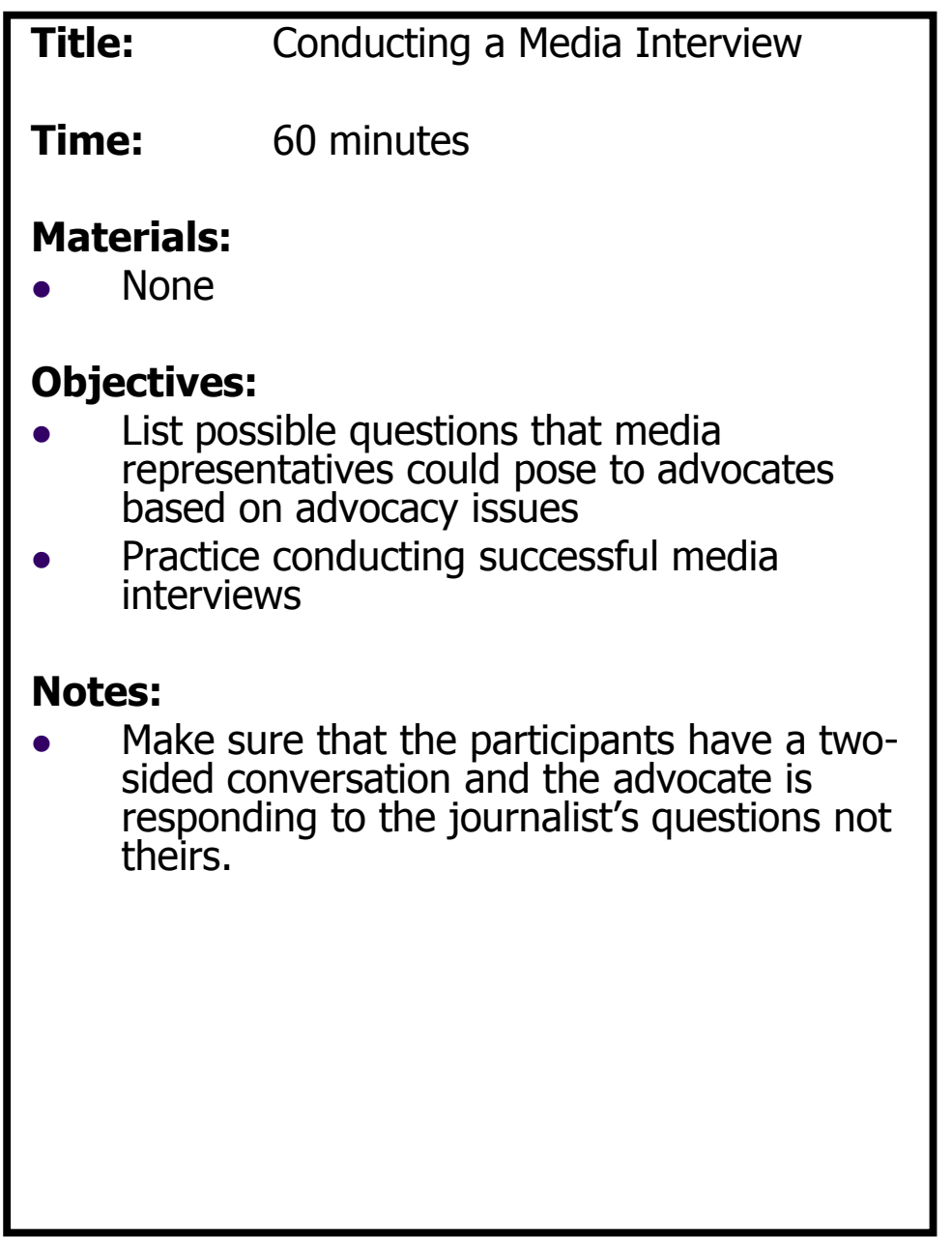

\section{Process}

- $\quad$ Read the statement to the participants

"A media interview is a conversation between a reporter and a person who has an interesting story that can be used as the basis for publication or broadcast. Media interviews are an advocacy method when (1)the general public has been identified as an 'indirect target' that will go on to influence others or when influential people are the targets of the article or broadcast item, for example, ministers reading a newspaper."

- $\quad$ Explain to the group that they are going to practice media interviews. Ask the whole group to agree on an HIV/AIDS advocacy issue and a target audience of influential people.

- Divide the group into pairs; one person will practice being an advocate, the other person will practice being a TV journalist.

- $\quad$ Ask the interviewees to prepare responses to possible questions on the issue and journalists to develop a series of questions for them in 5 minutes 


\section{Session 10: Media Interview}

\section{Process 2}

- $\quad$ Ask the pairs to practice doing a TV interview.

Paying attention to:

(1) Delivering key messages

(2) Answering questions clearly

(3) Physical composure

- Go around the room and listen to the pairs, offer feedback and advice on how the interview could be improved.

- $\quad$ Select random pairs to perform an interview for the group.

- $\quad$ After the role-play, encourage the group to assess the interview based on the components listed above.

- $\quad$ Conclude the session by discussing with the participants the differences between interviews for $T V$, radio and newspapers?

- Explain how the approaches to these media would differ during an interview 


\section{Session 11: Referrals}

Title: $\quad$ Effective Referrals
Time: $\quad 50$ minutes
Materials:
- $\quad$ Flip chart
- $\quad$ Markers
- $\quad$ Sample Referral Form
Objectives:
- $\quad$ Explain the concept of referrals
- Identify situations that require
referrals
- List out HIV/AIDS \& SRH resources
available in the community to serve as
referral sites
Notes:
- Prepare flip chart with definition of
referrals
Make sure participants include legal,
livelihood/skills acquisition, VCCT and
adult literacy sites in their list.
The list should be typed and mass
produced for all the participants

\section{Process}

- Begin the session by telling the participant that during the course of their work as community advocates they might come across persons that might need counseling or health care services. To adequately meet these needs, they would need to understand the concepts of referrals.

- Ask for volunteers to provide a definition of referrals. Harmonize definitions by presenting the definition in notes.

- Break participants into 2 groups and ask them to list out situations where persons might need HIV/AIDS \& RH services and should be referred. Allocate 10 minutes for task.

- $\quad$ After the presentation, facilitator should make additions, if omissions were observed

- Explain to participants that since they are all from different communities, it is important to think about the resources available in the community.

- $\quad$ Grouping by communities, participants should list the HIV/AIDS and SRH resources in the community.

- $\quad$ Conclude the session by reading out scenarios to participants and ask what type of referrals they would make. 


\section{Module Overview}

\section{Module 5: Planning and M\&E}

As the final module, this component enables the participants to develop action points and plans to put knowledge into practices as they go back into their communities. The module also features sessions to enable participants capture/document their activities and monitor progress as stated in their plans.

Session 1

Session 2

Session 3

Session 4

Total Module Time:
Developing Action Plans

Logistical Preparations for Activities

Monitoring of Activities

Evaluation of Workshop Activities
60 mins

60 mins

60 mins

30 mins

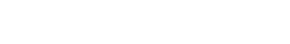




\section{Session 1: Developing Action Plans}

\begin{tabular}{|l|}
\hline Title: $\quad$ Developing Action Plans \\
Time: $\quad 60$ minutes \\
Materials: \\
- $\quad$ Flip charts \\
Objectives: \\
- $\quad$ Define action plan \\
- $\quad$ Devel the purpose of action plans \\
Notes: \\
If participants are not literate, assist \\
them to fill out the table by probing for \\
each component of the table \\
Help participants identify all possible \\
actions that they can undertake \\
Stress the need for the participants to \\
only write activities they are sure they \\
would be able to carry out \\
Keep a copy of the final action plans for \\
record and make sure each participant \\
has a copy \\
\end{tabular}

\section{Process}

- $\quad$ Tell the participants: "As we discussed during the $1^{\text {st }}$ day of the workshop, we are going to carry out some activities at the end of the or profession and ask them to fill out the action plan table based on activities they intend on conducting.

- Participants should present their action plans and clarifications should be made.

- $\quad$ The action plans should be typed and redistributed back to the participants for record keeping purpose workshop when we go back to our communities".

- Begin by asking participants who have seen or developed an action plan. Brainstorm what an action plan is and flip chart/record responses

- $\quad$ Present the definition of action plan and harmonize responses by participants

- Participants should brainstorm the purpose of action plans. Clarify mistakes and include omitted responses.

- $\quad$ Present flip chart with action plan table. Explain the various components.

- $\quad$ Divide the participants based on similar characteristics e.g. community 


\section{Session 2: Logistical Arrangement for Activities}

Title: $\quad$ Making Logistic Arrangement
Time: $\quad 60$ minutes
Materials:
- $\quad$ Flip charts
$\quad$ Markers
Objectives:
- Identify the logistical requirement need
for proposed advocacy activity
Notes:
- Make sure that participants report on
presentation in 3 formats : (1) Before
event; (2) During event and (3) After
event
Pay attention to omitted tasks that need
to be undertaken for implementation of
an advocacy activity.

\section{Process}

- Tell the participants that now they have listed out the different things that they would like to do after the training, it is important to explore how it will be done.

- In the action plan table there is a the "resource" column. We are going to go through these resources and see how we will plan each activities.

- $\quad$ Ask each group to select one activity from their work plan. With this activity, they should list all the steps they would have to take to carry out the activity. These steps should focus on the preparation they would have to make before, during and after the activity/event.

- $\quad$ The groups should make their presentation in plenary and the facilitator should make sure that the presentation have taken into consideration all logistical arrangement

- $\quad$ Summarize the session by telling participants that when they would like to undertake an activity based on their plans, they should go through each one the way this activity was conducted to make sure that nothing is forgotten. 


\section{Session 3: Monitoring of Activities}

Title: Monitoring and Record Keeping

Time: $\quad 60$ minutes

\section{Materials:}

- $\quad$ Flip charts

- Markers

\section{Objectives:}

- Identify the importance of record keeping

- Develop indicators for proposed activities

- $\quad$ Review of the Population Council monitoring forms

\section{Notes:}

- $\quad$ Obtain and review PC monitoring forms ahead of time

- Mass produce copies of these forms for distribution to the participants

- $\quad$ Support participants that might have challenges with creating indicators by using illustrations that are community orientated

\section{Process}

- $\quad$ Ask the participants to brainstorm the definition of record keeping and flip chart/record the responses.

- Also ask the participants to brainstorm the importance of record keeping, flip chart/record responses.

- Explain what the term "indicators" mean using the illustration below.

"Indicators are signs we use to check if we have carried out our activities. For example, if we are planning a trip to go from Kano to Lagos, what are the signs we will see to know we are going the right way'.

- Using the activities listed in the action plan, ask the participants to write indicators for each.

- $\quad$ The participants should present their indicators in plenary. If time is limited take indicators for only one activity for each group.

- $\quad$ Distribute the PC advocacy activity monitoring forms and review each component with participants.

- Allocate 10 minutes for questions and clarifications 


\section{Session 4: Evaluation of the Workshop}

\section{Title:

$$
\text { Evaluation of Workshop }
$$
Activities

Time:

30 minutes

\section{Materials:}

- $\quad$ Flip charts

- $\quad$ Multiple colored markers

\section{Objectives:}

- $\quad$ Evaluate progress and participant's assessment of workshop

- $\quad$ Obtain useful information to make workshop more participant centered

\section{Notes:}

- $\quad$ This can be conducted at the end of each day to assess participants satisfaction with the workshop sessions.

- It can be conducted by a sample of the participants or all the participants

- $\quad$ Prepare evaluation flip chart ahead of time

- Document participant's responses and discuss with other facilitators during planning meetings.

\section{Process}

- $\quad$ After the last session for each day, ask all the participants to provide information about how the workshop activities went.

- Inform them that their assessment should be as honest as possible because it will help to identify gaps and make the workshop more meaningful for them.

- Draw on the flip chart three headings (1) Content represented by a book; (2) Presentations represented by a small face and (3) Timing represented by a clock. On the side of the flip chart write the number/title of the sessions

- $\quad$ Explain each of the components as follows: Content - what we taught, was it enjoyable, relevant and worthwhile

Presentation - How the facilitator conducted each exercise. Was it done badly or well Timing - Was the time too long/short or enough

- $\quad$ Each category can have a mark of 1 to 5 , with 1 the lowest and 5 the highest. They should rate the categories by writing the numbers or markings to represent the ratings.

- Thank the participants for completing the task and note responses for each day. 